\title{
Secondary organic aerosol formation from gasoline vehicle emissions in a new mobile environmental reaction chamber
}

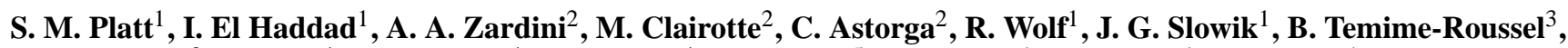 \\ N. Marchand ${ }^{3}$, I. Ježek ${ }^{4}$, L. Drinovec ${ }^{4}$, G. Močnik ${ }^{4}$, O. Möhler ${ }^{5}$, R. Richter ${ }^{1}$, P. Barmet ${ }^{1}$, F. Bianchi ${ }^{1}$, \\ U. Baltensperger ${ }^{1}$, and A. S. H. Prévôt ${ }^{1}$ \\ ${ }^{1}$ Laboratory of Atmospheric Chemistry, Paul Scherrer Institute (PSI), Villigen, 5232, Switzerland \\ ${ }^{2}$ Institute for Energy and Transport, Sustainable Transport Unit, European Commission Joint Research Centre, \\ 21027 Ispra, Italy \\ ${ }^{3}$ Aix-Marseille Université, CNRS, LCE FRE 3416, 13331, Marseille, France \\ ${ }^{4}$ Aerosol d.o.o., 100 Ljubljana, Slovenia \\ ${ }^{5}$ Institute for Meteorology and Climate Research, Karlsruhe Institute of Technology, 76021 Karlsruhe, Germany \\ Correspondence to: A. S. H. Prévôt (andre.prevot@psi.ch)
}

Received: 21 September 2012 - Published in Atmos. Chem. Phys. Discuss.: 26 October 2012

Revised: 8 July 2013 - Accepted: 11 July 2013 - Published: 16 September 2013

\begin{abstract}
We present a new mobile environmental reaction chamber for the simulation of the atmospheric aging of different emission sources without limitation from the instruments or facilities available at any single site. Photochemistry is simulated using a set of 40 UV lights (total power $4 \mathrm{KW})$. Characterisation of the emission spectrum of these lights shows that atmospheric aging of emissions may be simulated over a range of temperatures $\left(-7\right.$ to $\left.25^{\circ} \mathrm{C}\right)$. A photolysis rate of $\mathrm{NO}_{2}, J_{\mathrm{NO}_{2}}$, of $(8.0 \pm 0.7) \times 10^{-3} \mathrm{~s}^{-1}$ was determined at $25^{\circ} \mathrm{C}$. We demonstrate the utility of this new system by presenting results on the aging $\left(\mathrm{OH}=12 \times 10^{6} \mathrm{~cm}^{-3} \mathrm{~h}\right)$ of emissions from a modern (Euro 5) gasoline car operated during a driving cycle (New European Driving Cycle, NEDC) on a chassis dynamometer in a vehicle test cell. Emissions from the entire NEDC were sampled and aged in the chamber. Total organic aerosol (OA; primary organic aerosol (POA) emission + secondary organic aerosol (SOA) formation) was (369.8$397.5) 10^{-3} \mathrm{~g} \mathrm{~kg}^{-1}$ fuel, or (13.2-15.4) $\times 10^{-3} \mathrm{~g} \mathrm{~km}^{-1}$, after aging, with aged OA/POA in the range 9-15. A thorough investigation of the composition of the gas phase emissions suggests that the observed SOA is from previously unconsidered precursors and processes. This large enhancement in particulate matter mass from gasoline vehicle aerosol emissions due to SOA formation, if it occurs across a wider range of gasoline vehicles, would have significant implications for
\end{abstract}

our understanding of the contribution of on-road gasoline vehicles to ambient aerosols.

\section{Introduction}

Airborne particulate matter (PM) damages health (Dockery et al., 1993; Dockery and Pope, 1994) and affects climate (IPCC, 2007). A significant fraction of the total ambient aerosol mass is secondary organic aerosol (SOA), formed via the reactions of precursors (Hallquist et al., 2009). These precursors comprise gas phase volatile organic compounds (VOCs) or condensed phase matter which partitions at least to some extent to the gas phase (Donahue et al., 2006; Robinson et al., 2007). Therefore any source of VOCs or primary, directly emitted, organic aerosol (POA) may be associated with the production of SOA. In this context vehicular exhaust is an important source of primary PM and VOCs, particularly in urban areas where the health implications of pollutants are greater due to higher population density (EEA, 2006). Unfortunately, little or no information on SOA formation from vehicle emissions exists in the literature. Furthermore, how SOA production varies by vehicle type (e.g. diesel or gasoline, vehicle legislative standard etc.) and thus the relative contribution of different vehicle classes to ambient PM, remains poorly constrained. For example, top-down estimations of SOA production from vehicle exhaust have yielded contradictory results. Recent ambient aerosol mass 
Table 1. Overview of instrumentation used to study the aging of emissions in the mobile smog chamber.

\begin{tabular}{|c|c|c|c|}
\hline Measured parameter & Instrument & Manufacturer & Lower limit/range \\
\hline $\begin{array}{l}\text { Size resolved non-refractory par- } \\
\text { ticulate matter (mainly organics } \\
\text { (OA), nitrates, sulfates, ammo- } \\
\text { nium, chloride) }\end{array}$ & $\begin{array}{l}\text { High-resolution time-of-flight } \\
\text { aerosol mass spectrometer (HR- } \\
\text { ToF-AMS) with high pressure } \\
\text { lens }\end{array}$ & Aerodyne & $<1 \mu \mathrm{g} \mathrm{m}^{-3} / \mathrm{D}_{P} 0.1-2.5 \mu \mathrm{m}$ \\
\hline $\begin{array}{l}\text { Number-weighted aerosol size } \\
\text { distribution }\end{array}$ & $\begin{array}{l}\text { Scanning mobility particle sizer } \\
\text { (SMPS) }\end{array}$ & $\begin{array}{l}\text { Home built, with TSI long } \\
\text { DMA, TSI } 3022 \text { CPC }\end{array}$ & $0.01 \mathrm{~cm}^{-3}, \mathrm{D}_{P} 15-850 \mathrm{~nm}$ \\
\hline Black carbon (BC) & Aethalometer AE33 (beta) & Aerosol d.o.o. & $\begin{array}{l}30 \mathrm{ng} \mathrm{m}^{-3} \\
10 \mathrm{ng} \mathrm{m}^{-3}>100 \mathrm{ng} \mathrm{m}^{-3}\end{array}$ \\
\hline Particle number & $\begin{array}{l}\text { Condensation particle counter } \\
\text { CPC } 3776\end{array}$ & TSI & $\begin{array}{l}4 \mathrm{~nm}, \\
0.01-10^{7} \text { particles } \mathrm{cm}^{-3}\end{array}$ \\
\hline $\mathrm{NO}+\mathrm{NO}_{\mathrm{y}}($ trace level$)$ & $\mathrm{NO}_{\mathrm{x}}$ monitor $42 \mathrm{C}$ & Thermo Environmental & $0-200 \mathrm{ppb}$ \\
\hline $\mathrm{NO}+\mathrm{NO}_{\mathrm{y}}$ & $\mathrm{NO}_{\mathrm{x}}$ monitor $9841 \mathrm{~A}$ & Monitor Labs & $0-2000 \mathrm{ppb}$ \\
\hline $\mathrm{O}_{3}$ & $\begin{array}{l}\text { UV photometric } \mathrm{O}_{3} \text { analyser } \\
\text { model } 49 \mathrm{C}\end{array}$ & Monitor Labs & $0.05-1.0 \mathrm{ppm}$ \\
\hline $\mathrm{CO}_{2}+\mathrm{CO}+\mathrm{CH}_{4}+\mathrm{H}_{2} \mathrm{O}$ & $\begin{array}{l}\text { Picarro Cavity Ring-Down Spec- } \\
\text { trometer G2401 }\end{array}$ & Picarro & $\begin{array}{l}0-1000 \mathrm{ppm}\left(\mathrm{CO}_{2}\right) \\
0-5 \mathrm{ppm}(\mathrm{CO}) \\
0-20 \mathrm{ppm}\left(\mathrm{CH}_{4}\right) \\
0-7 \%\left(\mathrm{H}_{2} \mathrm{O}\right)\end{array}$ \\
\hline Total hydrocarbon (THC) & THC monitor APHA-370 & Horiba & $0.02-100 \mathrm{ppmC}$ \\
\hline $\begin{array}{l}\text { Trace volatile organic } \\
\text { compounds (VOCs) }\end{array}$ & $\begin{array}{l}\text { Proton time-of-flight mass spec- } \\
\text { trometer (PTR-ToF-MS) }\end{array}$ & Ionicon Analytik & $10 \mathrm{ppt}-1 \mathrm{ppm}$ \\
\hline $\begin{array}{l}\text { Relative humidity and } \\
\text { temperature }\end{array}$ & Dew point hygrometer SC-05 & Rotronic & RH $0-100 \%,-40-100^{\circ} \mathrm{C}$ \\
\hline Temperature & Thermocouple type K & Messelemente & $0-1200^{\circ} \mathrm{C}$ \\
\hline
\end{tabular}

spectrometer measurements in the Los Angeles Basin concluded that secondary organic aerosol (SOA) from gasoline vehicle emissions can dominate background urban organic aerosol (Bahreini et al., 2012). Conversely, another recent study has suggested, using raw diesel fuel combined with tunnel measurements, that diesel vehicles produce more SOA than gasoline vehicles (Gentner et al., 2012). Bottom-up estimations of SOA production from real tailpipe vehicular emissions are therefore needed.

Environmental reaction chambers or smog chambers are of considerable utility in the study of SOA formation (Hallquist et al., 2009, and references therein). However, the generation of realistic emissions from many combustion sources (including vehicle engines) under controlled, highly repeatable, conditions typically requires specialist testing facilities (e.g. chassis dynamometers) not generally accessible to large, stationary, smog chambers. For ambient studies a further limitation is that only air in the immediate vicinity of the smog chamber may be sampled. Here, we present the new Paul Scherrer Institute (PSI) mobile smog chamber constructed to overcome these limitations. Some features of this chamber are similar to those of the mobile chamber used by Carnegie Mellon University (CMU), see, e.g. Presto et al. (2011). We demonstrate the utility of the mobile smog chamber by in- vestigating and quantifying SOA formation from a modern (Euro 5) gasoline light-duty vehicle from the New European Driving Cycle (NEDC, see, e.g. Barlow et al., 2009) on a chassis dynamometer. These experiments required the transport to, installation, and operation of the chamber at a second facility, the European Commission Joint Research Centre (JRC), Italy.

\section{Materials and methods}

\subsection{Mobile smog chamber and integrated systems}

The mobile chamber set-up during the gasoline vehicle emissions aging experiments is illustrated in Fig. 1, which also highlights the modular design of the mobile smog chamber. Instrumentation used in this study is listed in Table 1. The design offers significant flexibility in terms of installation and operation at host facilities. For example during the gasoline vehicle emissions aging experiments, the chamber and sampling system was placed inside a testing cell with the vehicle, while the instruments and injection system were operated from outside of the cell. This allowed access to instrumentation during testing as well as a precise control of the chamber 


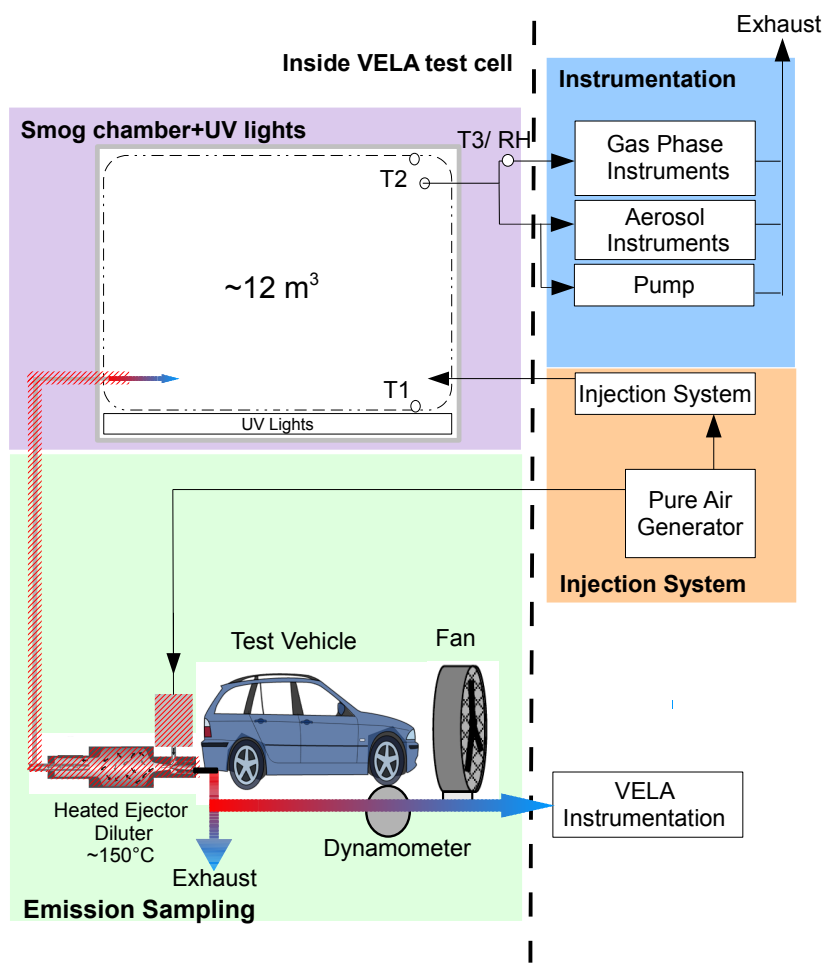

Fig. 1. Schematic (not to scale) of the mobile chamber as set up during experiments on a Euro 5 gasoline light-duty vehicle at the vehicle emissions laboratory (VELA) of the European Commission Joint Research Centre (JRC), Ispra, Italy. Highlighted are different sections of the set-up. Green: emissions sampling is performed using a modified Dekati ejector equipped with a pressurized air heater. Purple: the smog chamber, an approximately $12.5 \mathrm{~m}^{3}$ (when full), nominally $9 \mathrm{~m}^{3}(2.5 \mathrm{~m} \times 1.8 \mathrm{~m} \times 1.9 \mathrm{~m}, \mathrm{~L} \times \mathrm{W} \times \mathrm{H}), 125 \mu \mathrm{m}$ thick collapsible Teflon bag (suspended from a mobile aluminium frame $(2.3 \mathrm{~m} \times 2 \mathrm{~m} \times 2.5 \mathrm{~m}, \mathrm{~L} \times \mathrm{W} \times \mathrm{H})$ with a battery of $40100 \mathrm{~W} \mathrm{UV}$ lights. Orange: injection system and pure air generator. Blue: instrumentation, which was located outside of the test cell. Gas phase instruments are connected to the chamber via Teflon tubing, while steel or copper tubing is used to connect aerosol instruments.

temperature. Photographs illustrating this set-up are shown in Fig. S1, in the Supplement.

The mobile smog chamber (Fig. 1, purple) is an approximately $12 \mathrm{~m}^{3}$ (when full), nominally $9 \mathrm{~m}^{3}$ $(2.5 \mathrm{~m} \times 1.8 \mathrm{~m} \times 1.9 \mathrm{~m}, \quad \mathrm{~L} \times \mathrm{W} \times \mathrm{H}), \quad 125 \mu \mathrm{m}$ thick collapsible Teflon bag (DuPont Teflon fluorocarbon film (FEP), type 500A, Foiltec $\mathrm{GmbH}$, Germany) suspended from a mobile aluminium frame $(2.3 \mathrm{~m} \times 2 \mathrm{~m} \times 2.5 \mathrm{~m}, \mathrm{~L} \times \mathrm{W} \times \mathrm{H})$ with a battery of $40 \times 100 \mathrm{~W}$ UV lights (Cleo Performance solarium lamps, Phillips).

Controlling concentrations of gas phase species (e.g. $\left.\mathrm{NO}_{\mathrm{x}}\right)$ inside smog chambers is necessary in order to simulate atmospheric processes, see Sect. 2.3.2. Therefore, as illustrated in Fig. 2, the chamber is connected to an injection system, allowing the input of gases or liquids under controlled conditions. The injection system consists of a pure air genera-

\begin{tabular}{|c|c|c|c|c|c|c|c|}
\hline \multicolumn{8}{|l|}{ Key: } \\
\hline- & $\begin{array}{l}\text { Steel// } \\
\text { Teflon } \\
\text { Lines }\end{array}$ & "remen,. & $\begin{array}{r}\text { Heated } \\
\text { Lines }\end{array}$ & $\square$ & $\begin{array}{l}\text { Mass Flow } \\
\text { Controller }\end{array}$ & $\infty$ & $\begin{array}{l}\text { Two } \\
\text { Way } \\
\text { valve }\end{array}$ \\
\hline$\triangle$ & $\begin{array}{l}\text { Three } \\
\text { Way } \\
\text { Valve }\end{array}$ & \multicolumn{2}{|c|}{-(D) Compressor } & \multicolumn{2}{|c|}{ ○ Rotameter } & & $\begin{array}{r}\text { Gas } \\
\text { Bottle }\end{array}$ \\
\hline
\end{tabular}

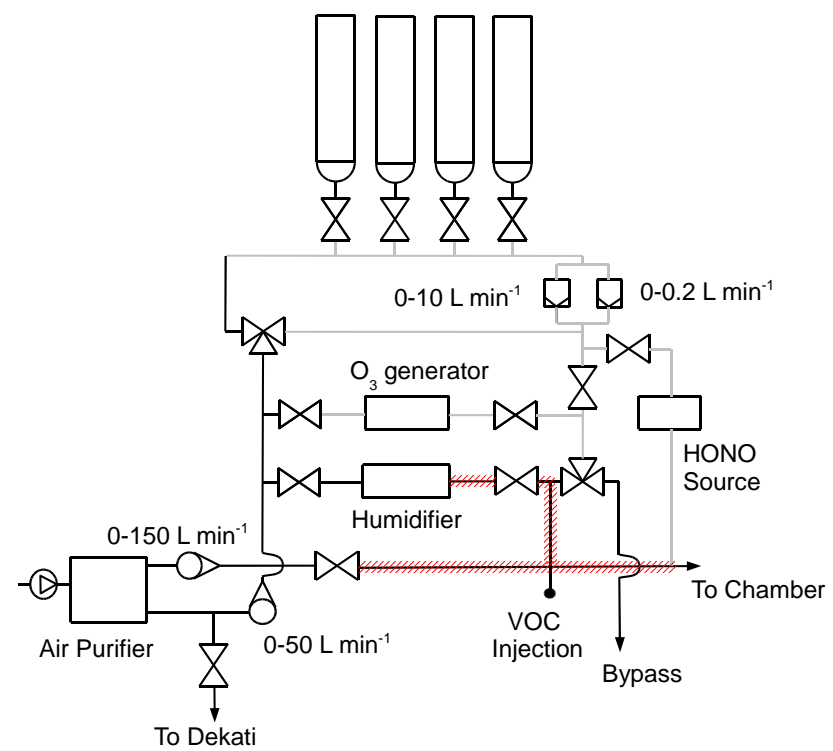

Fig. 2. Schematic (not to scale) of the primary component injection system of the mobile chamber. Pure air may be injected directly into the chamber through the main injection line, an insulated $12 \mathrm{~mm}$ (outer diameter) stainless steel tube which can be heated up to a maximum of $150^{\circ} \mathrm{C}$ (red hatching, "To Chamber"). All or part of the pure air stream may be diverted through different sections of the primary injection system using a series of two- and three-way valves.

tor (Atlas Copco SF 1 oil-free scroll compressor with $270 \mathrm{~L}$ container, Atlas Copco AG, Switzerland) with an air purifier (AADCO 250 series, AADCO Instruments, Inc., USA) coupled to an injection system. Pure air can be injected directly into the chamber through the main injection line, an extendable, insulated $12 \mathrm{~mm}$ stainless steel tube, which can be heated up to $150^{\circ} \mathrm{C}$ (Fig. 2, red hatching, "To Chamber"). The maximum operational flow rate from the pure air generation system is $120 \mathrm{~L} \mathrm{~min}^{-1}$. Since the Teflon bag is not fixed onto the frame, but rather suspended from rollers, the volume of the chamber may be adjusted by filling with pure air or withdrawing air through a pump. Rapid cleaning of the chamber is therefore possible by sequentially reducing the bag volume to around $1 \mathrm{~m}^{3}$ and flushing with $\mathrm{O}_{3}$ and humidified, pure air, see Sect. 2.3.2.

All or part of the pure air stream may be diverted through different sections of the injection system using a series of two- and three-way valves. The ratio of direct air into the main line to air through the injection system is controlled 
using rotameters. Gaseous components, e.g. $\mathrm{NO}, \mathrm{NO}_{2}$, or propene $\left(\mathrm{C}_{3} \mathrm{H}_{6}\right)$, are injected from gas bottles through one of two mass flow controllers: a low flow at $1-1000 \mathrm{~mL} \mathrm{~min}^{-1}$ or a high flow at $1-10 \mathrm{~L} \mathrm{~min}^{-1}$. Air inside the chamber can be humidified by diverting part of the pure air at $\sim 20 \mathrm{~L} \mathrm{~min}^{-1}$ through a glass flask containing heated MilliQ water. To prevent condensation, heated $\left(\sim 80^{\circ} \mathrm{C}\right)$ stainless steel tubing (red hatching, Fig. 2) is used after the flask and the humidified stream is re-combined with dry air in the main line, also heated to $\sim 80^{\circ} \mathrm{C} . \mathrm{O}_{3}$ is generated by passing pure air over a UV light source housed inside a stainless steel cylinder. Using this system $\mathrm{O}_{3}$ concentrations in the range of ppb-ppm can be generated inside the chamber. Liquid volatile organic compounds (VOCs) can be injected through a septum into the main injection line. Nitrous acid (HONO), used as a source of $\mathrm{OH}$ radicals, may be injected into the chamber using the continuous HONO generation system described by Taira and Kanda (1990). Briefly, constant flows of sodium nitrite and sulfuric acid, regulated by a programmable peristaltic pump (REGLO Digital MS-4/8, IDEX Health \& Science GmbH, Germany), are reacted in a custom-built glass vessel to produce HONO. Pure air passes through the vessel to purge the HONO and then through a polytetrafluoroethylene (PTFE) filter before injection into the chamber. Waste chemical solution is removed from the vessel by the peristaltic pump.

Emissions sampling into the chamber is performed using a modified ejector dilutor (DI-1000, Dekati Ltd, Finland), equipped with a pressurized air heater (DH-1723, Dekati Ltd, Finland). The Dekati is placed inside a stainless steel housing, which can be heated up to $200^{\circ} \mathrm{C}$, to reduce VOC and particle losses. The sampling lines are constructed from separable $2 \mathrm{~m}$ segments of insulated $12 \mathrm{~mm}$ silica steel tubing (outer diameter), also heatable up to $150{ }^{\circ} \mathrm{C}$. Using separable segments allows the distance between the chamber and emissions source to be varied as required, providing maximum flexibility in terms of installation at different facilities. Sampling lines to the instrumentation are of variable length and constructed from stainless steel or copper for aerosol sampling, and Teflon for gas phase sampling. Temperature probes are placed at the top and the bottom surface of the bag (Fig. 1, T1 and T2). Relative humidity (RH) and a third temperature reading, are measured in the sampling lines directly adjacent to the chamber (Fig. 1, RH/T3).

Data from the gas phase instruments $\left(\mathrm{NO}_{\mathrm{x}}, \mathrm{CO}_{2}\right.$, total hydrocarbon (THC), $\mathrm{O}_{3}$, Table 1 and Sect. 2.4) and the $\mathrm{RH}$ sensor are recorded and saved in real time using a data acquisition (DAQ) system (NI 92018 channel analogue input module and cDAQ-9178 8 slot USB chassis, National Instruments). Temperature at $\mathrm{T} 1$ and $\mathrm{T} 2$ is also recorded using the same DAQ system (NI 921416 channel module for high accuracy thermocouple measurements, National Instruments).

\subsection{Light characterisation experiments}

Actinometry experiments to determine the photolysis rate of $\mathrm{NO}_{2}\left(J_{\mathrm{NO}_{2}}\right)$ were performed to characterise the smog chamber lighting. Thus, $80 \mathrm{ppbv}$ of nitrogen monoxide (NO, 1000 ppmv, 5.0, in $\mathrm{N}_{2}$, Carbagas) was injected into the chamber followed by injection of ozone $\left(\mathrm{O}_{3}\right)$. After allowing several minutes for equilibration, the lights were switched on. $\mathrm{NO}_{\mathrm{x}}$ and $\mathrm{O}_{3}$ concentrations were monitored throughout (see Sect. 2.4.2 for details on smog chamber instrumentation).

The spectrum of the lights was measured using a photometer (USB2000 UVVIS, Ocean Optics, Inc., USA). The effect of varying temperature on light emission, and accordingly photochemistry, was determined by placing a small number of UV lights inside a refrigeration unit and measuring the spectrum over the range -7 to $25^{\circ} \mathrm{C}$.

\subsection{Gasoline exhaust aging experiments}

We report the results of two emission aging experiments performed at the Vehicle Emission Laboratory (VELA) of the European Commission Joint Research Centre (JRC), on exhaust emissions from one EURO 5 gasoline light-duty vehicle (GLDV). The experiments were conducted on 13 October 2011 (Exp. 1) and 14 October 2011 (Exp. 2). The emissions were studied after injection into the smog chamber and directly at the tail pipe. The emission measurements from the smog chamber also allowed an assessment of the performance of the smog chamber during typical operating conditions, including wall losses, leak rates and sampling efficiencies, see Sect. 3.1.

\subsubsection{Vehicle Emission Laboratory testing procedure}

Emission tests were performed on a chassis dynamometer (two 48" roller benches, Maha GmbH) climatic test cell (temperature range -10 to $35^{\circ} \mathrm{C}$ ) equipped with a constant volume sampler (CVS) with a critical flow venturi (Horiba, Germany).The temperature inside the test cell was $22^{\circ} \mathrm{C}$ during the experiments. The GLDV is equipped with a three-waycatalyst and stop-start system; technical details for this vehicle are summarised in Table S1.

Emissions were generated during the New European Driving Cycle (Fig. 3, grey) used for type approval of light-duty vehicles in Europe. The test started after a mandatory minimum ambient temperature $\left(22^{\circ} \mathrm{C}\right)$ soaking time of $6 \mathrm{~h}$ and is made up of a first urban phase of $780 \mathrm{~s}$ followed by an extraurban phase of $400 \mathrm{~s}$, following EU Regulation 692/2008 (EC, 2008), as highlighted in Fig. 3. Regulated emissions (THC, NMHC, CO, $\mathrm{NO}_{\mathrm{x}}$, and $\mathrm{PM}$ ) were sampled from the CVS and measured offline onto heated filters (Heated Particulate Filter Module, Horiba HFU-4770) in accordance with Directive 70/220/EEC (EEC, 1970), and its following amendments by means of non-dispersive infrared (regulated $\mathrm{CO}$ and unregulated $\left.\mathrm{CO}_{2}\right)$, chemiluminiscence $\left(\mathrm{NO}_{\mathrm{x}}\right)$ 
Table 2. Initial and adjusted parameters inside the mobile smog chamber for the gasoline light-duty vehicle aging experiments. Addition of propene after $2 \mathrm{~h}$ during Exp. 1 and before lights-on for Exp. 2 resulted in adjusted $\mathrm{VOC} / \mathrm{NO}_{\mathrm{x}}$ ratios of around 6.

\begin{tabular}{|c|c|c|c|c|c|c|c|c|}
\hline \multirow[t]{2}{*}{ Experiment \# } & \multirow[t]{2}{*}{ Date } & \multicolumn{5}{|c|}{ Initial conditions (before lights-on and addition of propene) } & \multirow{2}{*}{$\begin{array}{l}\text { Adjusted THC } \\
\text { (ppmv) }\end{array}$} & \multirow{2}{*}{$\begin{array}{l}\text { Adjusted } \\
\text { VOC/NO }_{\mathrm{X}}\end{array}$} \\
\hline & & $\mathrm{RH} \%$ & $T\left({ }^{\circ} \mathrm{C}\right)$ & Ozone (ppbv) & THC (ppmv) & $\mathrm{NO}_{\mathrm{X}}(\mathrm{ppmv})$ & & \\
\hline 1 & 13.10 .2011 & 50 & 25.1 & $<10$ & 1.5 & 0.53 & 3.2 & 6.1 \\
\hline 2 & 14.10 .2011 & 64 & 23.6 & $<10$ & 1.4 & 0.41 & 2.3 & 5.6 \\
\hline
\end{tabular}

and flame ionisation detector (THC) (Horiba MEXA 7400 HTRLE). In addition, a time-resolved (1 Hz) tailpipe emission characterisation was performed with the same methods described above (for $\mathrm{CO}, \mathrm{THC}, \mathrm{NO}_{\mathrm{x}}$ and $\mathrm{CO}_{2}$ ) and with a high-resolution Fourier transform infrared spectrometer (HR-FTIR, MKS MultiGas analyser 2030, Wilmington, MA, USA) used to monitor alkanes and alkenes (e.g. methane, ethylene and toluene), nitrogen species $\left(\mathrm{NO}_{\mathrm{x}}\right.$ and ammonia), and oxygenated compounds such as formaldehyde, acetaldehyde, and ethanol (see Clairotte et al., 2011, for details). Finally, gaseous emissions were sampled from the CVS and analysed offline by dedicated gas chromatography (Agilent, model 6890 with dual column and FID), allowing measurement of gas phase species such as alkanes, alkenes and aromatic hydrocarbons. Prior to and immediately after each test, the CVS is flushed for 30 minutes with dilution air. Particle number, as well as total hydrocarbon measurements, $\mathrm{CO}$, and $\mathrm{CO}_{2}$ are all below detection at the start of any test.

\subsubsection{Smog chamber experimental procedure}

Prior to all experiments the mobile chamber is cleaned by reducing its volume to $\sim 1 \mathrm{~m}^{3}$ and flushing first with $\mathrm{O}_{3}$ and humidified air, illuminating the chamber with UV light for a period of around $1 \mathrm{~h}$ and then flushing with pure dry air for several hours, typically overnight. At the start of each experiment, the bag was filled to approximately two thirds full with humidified air (i.e. leaving a volume free for sample injection during several minutes). Emissions from the NEDC were then sampled directly at the vehicle tailpipe and injected into the chamber using the Dekati ejector dilutor. The Dekati and sampling lines were heated to $150^{\circ} \mathrm{C}$. Table 2 shows the initial conditions inside the smog chamber, after exhaust injection.

Subsequent to exhaust injection, the chamber was filled to close to maximum volume with pure air, ensuring more rapid mixing of the sample and allowing longer experiment times (since sampling from the chamber involves reducing its volume). An ambient relevant 30 to $15 \mu \mathrm{g} \mathrm{m}^{-3}$ of primary aerosol (sum of black carbon and primary organic) was injected into the chamber in experiments 1 and 2, respectively.

A period of several minutes was allowed for the equilibration inside the chamber and for characterisation of the primary emissions. Then, $1 \mu \mathrm{L}$ ( $\sim 20 \mathrm{ppbv})$ of nine-times deuter-

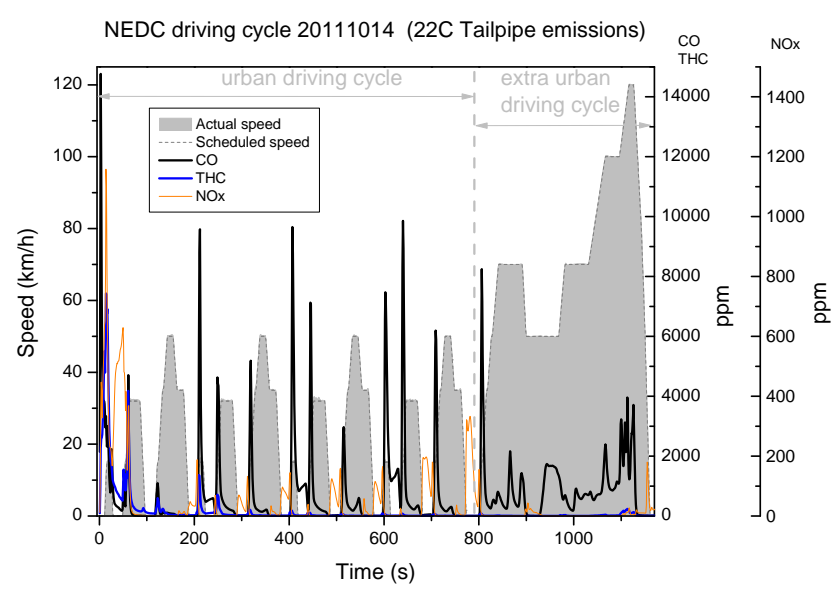

Fig. 3. Vehicle speed during the New European Driving Cycle (NEDC, grey, left axis) and average exhaust concentrations of the regulated compounds carbon monoxide ( $\mathrm{CO}$, black) and total hydrocarbon (THC, blue), both on the first right axis, and oxides of nitrogen $\left(\mathrm{NO}_{\mathrm{x}}\right.$, orange) on the second right axis for Exp. 2 during the driving cycle. The NEDC is split into two phases representing urban driving and a second phase representing extra-urban driving.

ated butanol (butanol-D9, $98 \%$ Aldritch) was injected to quantify $\mathrm{OH}$ exposure during the experiment (Barmet et al., 2012). Briefly, butanol-D9 is used as a unique $\mathrm{OH}$ tracer, and measuring its decay, here with the PTR-ToF-MS, yields time resolved $\mathrm{OH}$ concentrations.

Gasoline engines emit significant $\mathrm{NO}_{\mathrm{x}}$ (Fig. 3, orange). In the lower troposphere most $\mathrm{NO}_{\mathrm{x}}$ is present as $\mathrm{NO}_{2}$, therefore, ozone was injected to oxidise most NO to nitrogen dioxide $\left(\mathrm{NO}_{2}\right)$ prior to switching on the lights. Note that only enough ozone was added to convert the NO, and that an excess was not present before lights-on. Furthermore, propene (1000 ppm, 5.0, Carbagas) was added after two hours of lights-on for Exp. 1 and before lights-on for Exp. 2. to adjust the $\mathrm{VOC} / \mathrm{NO}_{\mathrm{x}}$ ratio to, in the case of these experiments, approximately 6:1 (see Table 2). The oxidation of propene is not likely to produce SOA (due to the high volatility of its oxidation products) and has previously been used to adjust the $\mathrm{VOC} / \mathrm{NO}_{\mathrm{x}}$ ratio during smog chamber experiments (Odum et al., 1996; Chirico et al., 2010). Previous studies have shown that propene can reduce SOA yields of aromatic hydrocarbons during smog chamber experiments by up to $15 \%$ by 


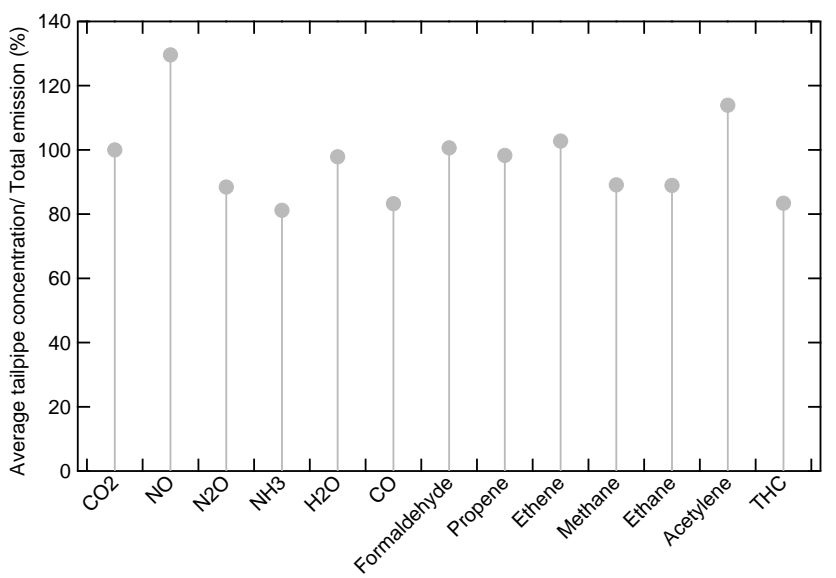

Fig. 4. $\mathrm{CO}_{2}$ normalised concentrations of gas phase species measured at the tailpipe (i.e. concentration of the constant flow injected into the smog chamber) vs. total mass emitted (i.e. accounting for variable exhaust flow as a function of time), measured using FTIR. Normalised concentrations are within $20 \%$ for most gas phase species, suggesting that sampling a constant flow from the vehicle exhaust yields samples with chemical composition close to those of the total emissions.

acting as an $\mathrm{OH}$ scavenger (Song et al., 2007), though this effect is quantified using the butanol-D9 tracer. Furthermore, propene addition resulted in a significant increase in $\mathrm{OH}$ radical production, as shown in Fig. S2. The addition of ozone and propene served therefore to shorten experiment times, while adjusting the conditions in the chamber to match more closely those of the ambient atmosphere.

After adjusting the gases in the chamber and after allowing time for instrument readings of the injected gases to stabilise, the UV lights were switched on to initiate photochemistry. Aging of the emissions and associated SOA production were measured during a period of $\sim 4 \mathrm{~h}$.

The procedure described here can be adapted for the study of other emissions, e.g. from ship engines, wood combustion etc. Adjustment of the $\mathrm{VOC} / \mathrm{NO}_{\mathrm{x}}$ ratio, if at all necessary, may in other studies also be achieved by the addition of $\mathrm{NO}_{\mathrm{x}}$, in cases where the $\mathrm{NO}_{\mathrm{x}}$ concentration is low in the chamber.

For this study the emissions were sampled directly at the tailpipe of the vehicle, thereby avoiding potential particle losses in the CVS. The CVS operates with a dynamic dilution system, ensuring that the total flow through the system is constant, even as exhaust flow rate varies during a driving cycle. This offers significant advantages in terms of quantification, and indeed is required for legislative testing, but is likely to incur losses of semi-volatile species as the system is not heated even at relatively low dilution. In this study, for example, the dilution in the CVS varied between 2 and 200, while the average dilution during the whole NEDC for both experiments was 37 , less than the dilution inside the chamber during both experiments (average dilution factor 100). The most significant disadvantage with sampling directly at the tailpipe is that while exhaust flow is variable, the sampled flow is constant. A different fraction of the complete exhaust is sampled as the flow rate varies. In theory this could lead to a sampled composition different from that which is emitted. However, Fig. 4 shows that the relative composition of the total VOC emission is very close, within $20 \%$, to that of the average tailpipe VOC emission (measured at the tailpipe using the FTIR). That is, tailpipe sampling offers the advantage of minimising losses while allowing quantification of emissions. For the results presented below, it is assumed that the composition of VOC sampled at the tailpipe is the same as that sampled at the CVS (e.g. from GC-FID analysis).

\subsection{Instrumentation}

Table 1 reports a non-exhaustive list of instrumentation typical of that available for measurements from the mobile chamber. These allow the characterisation and quantification of particle and gas phase species.

\subsubsection{Particle phase measurements}

Time-resolved online measurements of particle composition were performed using a high-resolution time-offlight aerosol mass spectrometer (HR-ToF-AMS) and an aethalometer (Model AE33 prototype). A detailed description of the working principles of the HR-ToF-AMS and associated data analysis may be found in DeCarlo et al. (2006). The instrument provides quantitative size-resolved mass spectra of non-refractory $\mathrm{PM}_{1}$ components, empirically defined as vaporisable species over a $1 \mathrm{~s}$ time interval, at $600^{\circ} \mathrm{C}$ and $10^{-7}$ torr. These include organic aerosol (OA) and ammonium nitrate and sulfate $\left(\mathrm{NH}_{4}^{+}, \mathrm{NO}_{3}^{-}\right.$and $\left.\mathrm{SO}_{4}^{2-}\right)$. Data from the high-resolution time-of-flight aerosol mass spectrometer are analysed using high-resolution analysis fitting procedures.

Black carbon (BC) concentrations and aerosol optical absorption spectra were measured using an aethalometer (Model AE33 prototype). This new aethalometer incorporates two simultaneous parallel sampling channels from the same inlet stream collected at different rates of accumulation, resulting in different loading of the filter with collected aerosols on the two respective spots. Loading effects can then be extrapolated to zero loading allowing online "loading effect" compensation for all wavelengths used for the measurement.

An important consideration in the quantitative analysis of AMS data is the collection efficiency (CE), related to particle bounce. Correcting scanning mobility particle sizer (SMPS) data from the chamber for density, based on the particle chemical composition measured by the HR-ToFAMS and subtracting black carbon (BC) as measured by the aethalometer, provides a second measurement of the total non-refractory PM mass (i.e. those species quantified in the HR-ToF-AMS). This was used to correct for CE, which 
was between 0.5-1.0 throughout both experiments, consistent with recent laboratory and ambient measurements of CE (Middlebrook et al., 2012; Matthew et al., 2008). Note that error is possible in the quantification of the primary particles, which have a relatively high content of $\mathrm{BC}$ characterised by a non-uniform shape, since the SMPS relies on mobility diameter. An overestimation of total primary emissions could be expected where black carbon content is large. However gravimetric analysis of primary emissions yielded similar primary emission factors (EFs), suggesting only minimal error in this case (see Sect. 3.3.2 and Fig. S3). Heavily SOAcoated particles are assumed to be spherical and therefore not to introduce error in the CE calculation. Data presented below are all corrected for CE.

The HR-ToF-AMS used for these experiments was equipped with a newly developed high pressure lens, which has a lower size limit of $100 \mathrm{~nm}$ for $100 \%$ transmission, and can sample aerosol larger than $2.5 \mu \mathrm{m}$ (Williams et al., 2013). Figure S5 shows volume distributions for fresh and aged aerosol during Exp. 2. The volume distribution grows significantly over the experiment. As shown, the primary volume distribution is centred at around $250 \mathrm{~nm}$, while most secondary particles are in the range $350-700 \mathrm{~nm}$. By using the large lens, around $40 \mathrm{~nm}$ are cut from the lower edge of the volume distribution $(<10 \%$ of the mass), while no part of the higher edge is cut. The standard lens would cut a small portion at both sides of the primary aerosol volume distribution. For the secondary aerosol the standard lens would cut a small portion of the larger particles, while none are cut by the large lens. Therefore, while both lenses could reasonably be used to measure the aging of aerosol from this vehicle, the high pressure lens is slightly better suited.

\subsubsection{Gas phase measurements}

A suite of gas phase instruments was used here and is typically available for studies using the mobile smog chamber. Reactive gases such as $\mathrm{O}_{3}$ and $\mathrm{NO}_{\mathrm{x}}$ are monitored throughout every experiment, while emphasis has been placed on the measurement of combustion products, e.g. $\mathrm{CO}_{2}, \mathrm{CO}, \mathrm{CH}_{4}$ and THC (Table 1), allowing establishment of the carbon mass balance of the emissions. $\mathrm{NO}_{\mathrm{x}}$ is monitored using instrumentation which measures directly $\mathrm{NO}$ as well as all nitrogen oxides $\left(\mathrm{NO}_{\mathrm{y}}\right)$, with $\mathrm{NO}_{\mathrm{y}}$ assumed to be almost exclusively $\mathrm{NO}_{2}$ during most experiments.

A proton transfer reaction time-of-flight mass spectrometer (PTR-ToF-MS, Ionicon Analytik) was used to measure concentrations of VOCs inside the chamber, including that of butanol-D9. The instrument performances have already been described in detail previously (Jordan et al., 2009; Graus et al., 2010). The high mass resolution of the PTR-ToF-MS $(\mathrm{m} / \Delta \mathrm{m}$ ranging from 3200 to 4500 between $\mathrm{m} / \mathrm{z} 21$ and $\mathrm{m} / \mathrm{z}$ 149) combined with an accuracy below $20 \mathrm{ppm}$ allows separation and formula assignment of most of the ions comprising the mass spectra of both primary and secondary ve- hicle emissions. Based on a 2 min integration time, typical limits of detection determined as the $3 \sigma$ uncertainty measured with a Pt catalyst heated at $350^{\circ} \mathrm{C}$ were below $10 \mathrm{ppt}$. Data analysis was carried out using ToF Viewer 1.4.3. ToFto-mass assignment was performed using hydronium ion isotope $\left(\mathrm{H}_{3}^{18} \mathrm{O}^{+}, 21.022\right)$ and protonated acetone $\left(\mathrm{C}_{3} \mathrm{H}_{7} \mathrm{O}^{+}\right.$, 59.049). Peak fitting and integration was performed using Gaussian functions.

\section{Results}

\subsection{Mobile chamber characterisation}

The suite of tests conducted (see Sect. 2.2) and emissions experiments (see Sect. 2.3) allowed us a detailed characterisation of the mobile chamber.

\subsubsection{Chamber blank and leak rate}

Figure 5 illustrates an example of results from the second emissions experiment, showing time series and concentrations of several gas phase species as well as organic aerosol concentrations measured from the smog chamber and the temperature inside the chamber. In the empty chamber, before sample injection, measured particle number concentration is always below the CPC detection limit $\left(<0.1 \mathrm{~cm}^{-3}\right)$, whereas the $\mathrm{CO}_{2}$ concentration is around 35 ppmv. By measuring the increase in $\mathrm{CO}_{2}$ and $\mathrm{CH}_{4}$ due to diffusion of external air into the empty chamber, an average leak rate of $0.08 \% \mathrm{~h}^{-1}$ (i.e. $\sim 9 \mathrm{~L} \mathrm{~h}^{-1}$ ) was calculated. These results show that the chamber has minimal contaminants and that leaks are minor over the course of a typical experiment lasting 5-6 h (see $\mathrm{CO}_{2}$, green trace, Fig. 5b).

Two blank experiments were performed, where the chamber was filled with either pure air, or a mix of pure air and ambient air sampled through the heated sampling system and the lights were switched on. In both experiments $<1 \mu \mathrm{g} \mathrm{m}^{-3}$ of aerosol was formed.

\subsubsection{Temperature control}

Since the chamber is not housed in an enclosure, the temperature inside the bag is that of the ambient. For the gasoline aging experiments the ventilation inside the VELA was sufficient to maintain a stable temperature to within $1{ }^{\circ} \mathrm{C}$, despite the heat generated by the UV lights (see Fig. 5a, grey). The temperature gradient was $<1{ }^{\circ} \mathrm{C}$ as measured using sensors T1 and T2 (Fig. 1).

\subsubsection{Particle loss rates}

During smog chamber experiments particles are lost to the walls through deposition following diffusion and gravitational settling. These losses limit the maximum duration of smog chamber experiments by continually removing 


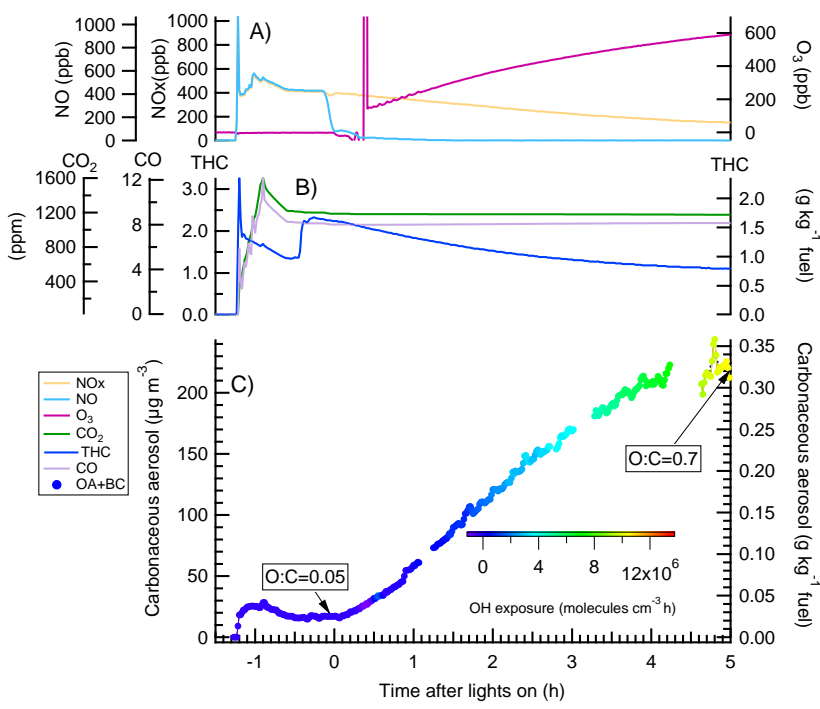

Fig. 5. Measured concentrations and calculated emissions factors (EFs) inside the mobile smog chamber of gas and particle phase species after injection of emissions from a Euro 5 gasoline lightduty vehicle (GLDV) (Exp. 2) as a function of time after lights-on in the chamber. (A) $\mathrm{NO}_{\mathrm{x}}$ (yellow), $\mathrm{NO}$ (light blue), $\mathrm{O}_{3}$ (magenta). After an initial spike due to sample injection, a small decrease in $\mathrm{NO}_{\mathrm{x}}$ before lights-on follows the injection of additional air required to completely fill the chamber. $\mathrm{O}_{3}$ increases after lights-on as a consequence of the photochemical processing of emissions occurring inside the chamber. Temperature is stable to within $1^{\circ} \mathrm{C}$ throughout the experiment. (B) Carbonaceous gases. After an initial decrease due to the dilution, $\mathrm{CO}_{2}$ (green) and $\mathrm{CO}$ (lilac) concentrations are constant indicating that the system is airtight. The increase in total hydrocarbon (blue) before lights-on follows the addition of propene required to adjust the $\mathrm{VOC} / \mathrm{NO}_{\mathrm{x}}$ ratio. (C) Wall loss corrected carbonaceous aerosol (black carbon, $\mathrm{BC}+$ organic aerosol, OA) increases after lights-on due to secondary organic aerosol (SOA) formation. $\mathrm{OH}$ exposure is shown by the colour scale. Aging increases the $\mathrm{O}: \mathrm{C}$ ratio of the emissions from 0.05 for the primary to 0.7 for the secondary, a ratio equivalent to the low volatility oxidised OA observed in highly aged ambient aerosols. The right axis in (B) and (C) shows the EF calculated for THC and carbonaceous aerosol using Eqs. (6) and (7).

suspended particle mass until instrument detection limits are reached. The loss rate for a given chamber depends largely on the surface to volume ratio of the chamber, with higher ratios leading to higher loss rates. Other parameters affecting particle loss rates include particle size (small particles have higher diffusion loss rates, while larger particles are more affected by gravitational settling) and turbulence inside the chamber, due to for example temperature gradients.

Aethalometer data, shown in Fig. S2 (SI), was used to determine particle loss rate to the chamber walls during the gasoline aging experiments based on the method adopted by Grieshop et al. (2009) and used in other combustion emission smog chamber studies (Saathoff et al., 2003). Briefly, by assuming an internally mixed aerosol, i.e. equal loss rate to the
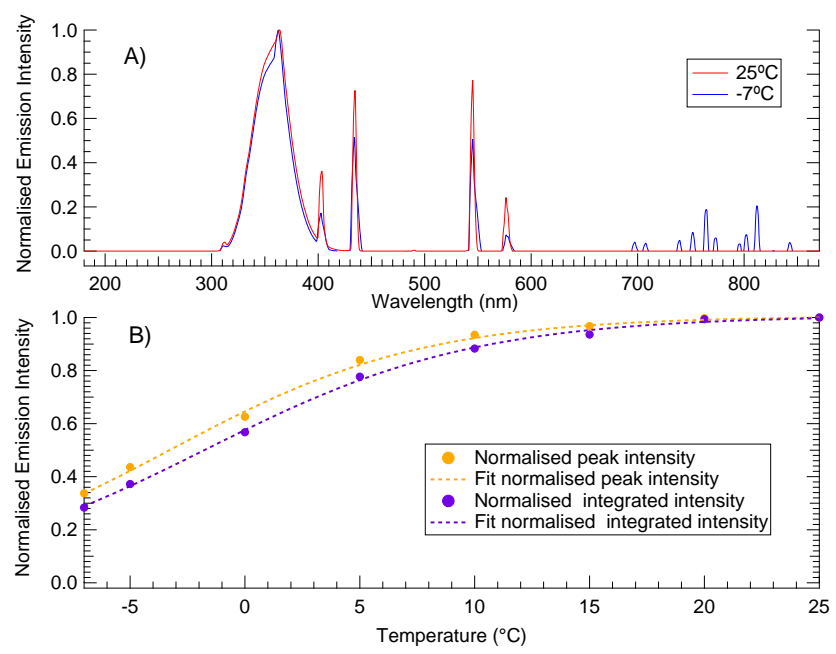

Fig. 6. (A) Emission spectrum of the UV black lights of the mobile smog chamber normalised to the peak in emission at $368 \mathrm{~nm}$ at $25^{\circ} \mathrm{C}$ (red) and $-7^{\circ} \mathrm{C}$ (blue). The emission fingerprint does not change significantly over this temperature range. (B) The normalised intensity of the smog chamber lighting measured at $368 \mathrm{~nm}$ and from integrating the full spectrum. The dashed lines show a power fit to the data. Intensity does not vary significantly between $10^{\circ} \mathrm{C}$ and $25^{\circ} \mathrm{C}$ (less than $\sim 10 \%$ decrease). At $-7^{\circ} \mathrm{C}$, intensity is decreased significantly ( $\sim 70 \%$ decrease).

walls of all aerosol species, BC can be used to infer a wall loss corrected PM mass $\left(\mathrm{PM}_{\mathrm{WLC}}\right)$ :

$\operatorname{PM}_{\mathrm{WLC}}(t)=\frac{\operatorname{PM}(t)}{\exp (-k t)}$,

where $t$ refers to experiment time and $k$ the exponential decay constant of the fitted period. Although $\mathrm{BC}$ is expected to be inert, aethalometer measurements are affected by coating of soot particles with SOA, which increases the effective absorption coefficient and hence apparent concentration (Saathoff et al., 2003), clearly visible in Fig. S2. Therefore, a fitted BC concentration is used. Figure S2 also shows two such fits, one before lights-on in the chamber, where no change in absorption from particle coating is expected, and one after $3 \mathrm{~h}$ of lights-on where particle growth is negligible. Fitted BC data (Fig. S2) indicate a particle half-life due to wall losses of between 3.3 and $4.0 \mathrm{~h}$ for the period before lights-on and the period after lights-on, respectively, for Exp. 2. The particle half-life was shorter during Exp. 1 and the average half-life determined using fitted aethalometer data from the primary emissions (before lights-on) over both experiments was $2.8 \pm 0.8 \mathrm{~h}$. These values indicate that particle losses in the chamber are sufficiently low to conduct experiments over several-hour timescales. Particle half-life in the mobile chamber is shorter than the average $5 \mathrm{~h} \mathrm{ob}$ served in the $27 \mathrm{~m}^{3}$ PSI stationary smog chamber (Paulsen et al., 2005), an expected consequence of the increased surface to volume ratio of the mobile chamber. Data presented 
here are all corrected for wall losses. The pre-UV exposure fit before lights-on was chosen to correct for losses as the fit after lights is more likely to be influenced by coating. Significant influences due to turbulence during aging as a result of heating from the lights are not expected as only a small change in temperature after UV light exposure was observed and a longer half-life is observed during lights-on (Fig. S2).

\subsubsection{Actinometry}

Figure 6a shows the light spectrum at $25^{\circ} \mathrm{C}$ (red) and $-7^{\circ} \mathrm{C}$ (blue) of the UV lights of the mobile smog chamber normalised to the peak intensity. The peak in emission is at $368 \mathrm{~nm}$ and is in a narrow window between 310 and $430 \mathrm{~nm}$. The emission fingerprint as a function of wavelength and temperature $(I(\lambda, T))$, of the smog chamber lighting overlaps with the absorption cross section $(\sigma(\lambda, T))$ for the photolysis of many important atmospheric trace gases including the $\mathrm{OH}$ radical sources $\mathrm{O}_{3}, \mathrm{HONO}$, and $\mathrm{HCHO}$, as well as $\mathrm{NO}_{2}$ (Carter, 1995). Therefore although emission intensity may be higher than sunlight over the spectral region at which UV lights emit and much of the solar spectrum is not represented, UV lights are a good substitute for ambient sunlight in smog chambers (Carter, 1995). An advantage of UV lights over other light sources, such as for example xenon arc lights, is that they do not produce significant heat. Consequently UV black lights are used in many environmental reaction chambers.

The photolysis rate of $\mathrm{NO}_{2}\left(J_{\mathrm{NO}_{2}}\right)$ can be calculated using the photostationary steady-state relation:

$\left[\mathrm{O}_{3}\right]=\frac{J_{\mathrm{NO}_{2}}\left[\mathrm{NO}_{2}\right]}{k[\mathrm{NO}]}$,

where the concentrations of $\mathrm{O}_{3}, \mathrm{NO}_{2}$ and $\mathrm{NO}$ as well as the rate constant $k$ between $\mathrm{O}_{3}$ and $\mathrm{NO}$ are known (Seinfeld and Pandis, 2006), in this case from smog chamber measurements. $\mathrm{NO}_{\mathrm{x}}$ was measured with both Thermo and Monitor Labs $\mathrm{NO}_{\mathrm{x}}$ analysers (Table 1), and an average $J_{\mathrm{NO}_{2}}$ of $(8.0 \pm 0.7) \times 10^{-3} \mathrm{~s}^{-1}$ was calculated from Eq. (2), after a correction of $5 \%$ to account for formation of $\mathrm{NO}_{2}$ in the (dark) sampling lines.

$J_{\mathrm{NO}_{2}}$ as a function of wavelength and temperature within a given window $\lambda 2-\lambda 1$ is given by

$$
J_{\mathrm{NO}_{2}}(\lambda, T)=\int_{\lambda 1}^{\lambda 2} \varphi_{\mathrm{NO}_{2}}(\lambda, T) \cdot \sigma_{\mathrm{NO}_{2}}(\lambda, T) \cdot I(\lambda, T) d \lambda,
$$

where $(\lambda, T)$ is the quantum yield of $\mathrm{NO}_{2}$ photolysis as a function of wavelength and temperature (Seinfeld and Pandis, 2006). Thus, while $I(\lambda, T)$ in Fig. $6 \mathrm{a}$ is given by the light photometer in arbitrary units only, absolute values for the photolysis rates of a compound $i\left(J_{i}\right)$ can be inferred from
$J_{\mathrm{NO}_{2}}$ :

$J_{i}=J_{\mathrm{NO}_{2}} \cdot \frac{\int_{\lambda 1}^{\lambda 2} \varphi_{i}(\lambda, T) \cdot \sigma_{i}(\lambda, T) \cdot I(\lambda, T) d \lambda}{\int_{\lambda 1}^{\lambda 2} \varphi_{\mathrm{NO}_{2}}(\lambda, T) \cdot \sigma_{\mathrm{NO}_{2}}(\lambda, T) \cdot I(\lambda, T) d \lambda}$.

Inferred photolysis rates at $25^{\circ} \mathrm{C}$ from Eq. (4) are given for several compounds in Table 5, where International Union of Pure and Applied Chemistry (IUPAC) recommended values of $\varphi(\lambda, T)$ and $\sigma(\lambda, T)$ (Atkinson et al., 2004, 2006) were used in Eq. (4). The predicted photolysis rates show that the lighting system of the mobile smog chamber can be expected to be particularly effective in generating $\mathrm{OH}$ radicals from $\mathrm{HONO}$ when in the presence of $\mathrm{NO}_{\mathrm{x}}$, and to a lesser extent from $\mathrm{O}_{3}$ and formaldehyde.

Figure 6 also shows that the emission fingerprint is largely unchanged over the given temperature range. Theoretical rate constants at $-7^{\circ} \mathrm{C}$, shown in Table 5, were also determined using Eq. (4). Methodology for the calculation of $\phi_{-7{ }^{\circ} \mathrm{C}}(\lambda)$ and $\sigma_{-7{ }^{\circ} \mathrm{C}}(\lambda)$ for each compound is given in the Supplement. For $I-7^{\circ} \mathrm{C}(\lambda)$, measured values (Fig. 6a, blue) were used. Table 5 also shows the ratio of gas phase photolysis rates $J_{i}$ at

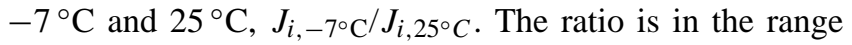
$0.30-0.41$, while the ratio in emission intensity at these temperatures, $I_{-7{ }^{\circ} \mathrm{C}}(\lambda) / I_{-25^{\circ} \mathrm{C}}(\lambda)$, is 0.28 (Fig. 6b). Therefore, the decrease in photolysis rates can be largely explained in terms of the decrease in emission intensity of the UV lights. A power fit (dashed lines Fig. 3b) of the measured intensity at different temperatures can therefore be used to predict the relative gas phase photolysis rate of species $i$ as a function of temperature $\left(J_{\text {rel }, i}(T)\right)$ :

$J_{\mathrm{rel}, i}(T)=J_{i}\left(25^{\circ} \mathrm{C}\right) \cdot\left(-0.064 \cdot\left(\frac{1.080}{1+\exp (-2.466-(T / 6.218)}\right)\right)$.

Equation (5) suggests that although significant loss of intensity occurs at low temperatures, the lighting in the mobile chamber will still initiate photochemistry. The mobile chamber can thus be utilised for aerosol aging studies even at zero or sub-zero temperatures. Under such conditions the HONO injection system described in Sect. 2.1 could be used to compensate for the loss in intensity by providing an additional OH source. As Fig. 6 illustrates the mobile chamber may be operated down to $\sim 10^{\circ} \mathrm{C}$ without large loss in light intensity.

For the gasoline aging experiments the $\mathrm{OH}$ exposure was zero before the lights were switched on. The integrated exposure at the end of each experiment, after UV light exposure and aging, was around $12 \times 10^{6}$ molecules $\mathrm{cm}^{-3} \mathrm{~h}$ (colour scale, Fig. 5). Assuming a global annual mean concentration of $10^{6} \mathrm{OH}$ molecules $\mathrm{cm}^{-3}$ (Prinn et al., 2001), this corresponds to $12 \mathrm{~h}$ in the atmosphere, thereby demonstrating that the lighting of the chamber generates sufficient $\mathrm{OH}$ to study atmospheric processes occurring over relevant timescales.

While this study shows that the mobile chamber lighting can be used to simulate atmospheric photochemistry over a range of temperatures, uncertainties remain. The photolysis rates of some compounds, notably ketones and aldehydes, 
may be enhanced compared to ambient conditions when using UV lights (Carter, 1995). Furthermore, oxidised SOA mass can be lost under UV black lights when $\mathrm{OH}$ concentration decreases from $10^{7}$ to $10^{6}$ molecules $\mathrm{cm}^{-3} \mathrm{~s}^{-1}$ (Donahue et al., 2012). This suggests that photolysis and other OA processing pathways initiated by the UV lights compete with the photooxidation pathways responsible for SOA formation. That is, the relative importance of SOA decay (due to photolysis pathways) compared to SOA production via $\mathrm{OH}$ oxidation is increased when $\mathrm{OH}$ concentration is lowered.

This is consistent with the photolysis rates in Table 5 . For example, using $k_{\mathrm{OH}}=1.1 \times 10^{-11} \mathrm{~cm}^{3}$ molecule ${ }^{-1} \mathrm{~s}^{-1}$ for glyoxal and $\mathrm{OH}=10^{6} \mathrm{~cm}^{-3}$, photolysis would account for $\sim 40 \%$ of glyoxal decay in the smog chamber. At $\mathrm{OH}=10^{7} \mathrm{~cm}^{-3}$ this drops to $\sim 6 \%$. Such effects could theoretically lead to an underestimation of the SOA production for the gasoline vehicle in this study relative to ambient conditions. However, the UV light and sunlight spectra overlap, thus the relative importance of the SOA formation/SOA processing (likely photolysis) pathways will depend both on relative light intensity and $\mathrm{OH}$ concentrations, each highly variable in smog chambers and the ambient atmosphere.

\subsection{Gasoline exhaust aging experiments}

Figure 5 shows the concentrations measured with respect to time for several gas phase species as well as organic aerosol concentrations measured from the smog chamber during Exp. 2. Using this data, emission factors for a pollutant $P$ per mass of combusted fuel ( $\left.\mathrm{EF}_{\mathrm{MASS}}\right)$, shown on the right axis for aerosol and hydrocarbon emissions as a function of time in Fig. 5, were calculated based on a carbon mass balance approach (adapted from Phuleria et al., 2006):

$\mathrm{EF}_{\mathrm{MASS}}=\left(\frac{\Delta P}{\Delta C_{\mathrm{CO}_{2}}+\Delta C_{\mathrm{CO}}+\Delta C_{\mathrm{HC}}+\Delta C_{\mathrm{OC}}+\Delta C_{\mathrm{BC}}}\right) \cdot W_{c}$,

where $C$ denotes carbon mass from $\mathrm{CO}_{2}, \mathrm{CO}$, gas phase hydrocarbon (HC), particle phase organic carbon (OC), from high-resolution AMS analysis (Aiken et al., 2008) and black carbon $(\mathrm{BC}) . W_{C}$ is the fuel carbon mass fraction, 0.859 , for the gasoline used. All values are determined from the change in concentration $(\Delta)$ observed in the smog chamber before and after sample injection or aging.

An emission factor per $\mathrm{km}\left(\mathrm{EF}_{\mathrm{KM}}\right)$ can then be calculated based on fuel economy:

$\mathrm{EF}_{\mathrm{KM}}=\mathrm{EF}_{\mathrm{MASS}} \cdot e \cdot \rho$,

where $e$ is the fuel economy, 5.27 and $5.22 \mathrm{~L} 100 \mathrm{~km}^{-1}$ for Exp. 1 and 2, respectively, and $\rho$ is the fuel density, $0.759 \mathrm{~kg} \mathrm{~L}^{-1}$ for the gasoline fuel used. Vehicle test cell (e.g. ambient temperature, humidity) and vehicle parameters (oil and catalyst temperatures) are presented in Table S3. Note that a period of several hours $(>5)$ is required for oil temperature to cool to initial temperature after the driving cycle. This highlights the importance of the "soaking time" (Sect. 2.3.1) in performing repeatable driving cycles.

\subsubsection{Primary emissions}

EFs for Exp. 1 and 2, determined from smog chamber data using Eqs. (6) and (7) for the Euro 5 GLDV regulated compounds, $\mathrm{CO}, \mathrm{HC}$, non-methane hydrocarbons (NMHC) and $\mathrm{NO}_{\mathrm{x}}$, from the primary emissions as well as the Euro 5 limit values, are shown in Table 3. HC and NMHC are reported in units of carbon mass, i.e. $\mathrm{g} \mathrm{C} \mathrm{kg}^{-1}$ fuel.

Exhaust VOCs measured using Fourier transform infrared (FTIR) spectroscopy and gas chromatography flame ionisation detection (GC-FID) are given in Table S4. Figure 7 shows exhaust VOCs measured at the CVS using GC-FID in addition to normalised methane and formaldehyde measured at the tailpipe and condensed phase material measured in the smog chamber. Data are presented as a carbon mass balance for fresh and aged emissions, as well as for raw gasoline (from data shown also in Table S2). An estimate of the aged gas phase (Fig. 7, aged emissions, red) is made by subtracting the aged secondary organic carbon from the initial VOC. The aged gas therefore incorporates gas phase reaction products including $\mathrm{CO}$ and $\mathrm{CO}_{2}$. Note that a considerable fraction of lighter hydrocarbons are produced, and that the aromatic hydrocarbon fraction $(\sim 10 \%)$ is somewhat reduced compared to the raw fuel used (29\%), indicating that raw fuel is not a good proxy for vehicular emitted hydrocarbon, at least not in this case. The large unidentified fraction of the hydrocarbon emission may include smaller oxygenated compounds, e.g. ethanol, longer chain and branched alkanes and measurement uncertainty. Most of this THC emission (>90\%) occurs at the start of the driving cycle (see Fig. 3), when the catalyst is cold, as is to be expected based from previous studies showing the importance of the cold start, e.g. Weilenmann et al. (2009).

As shown from the CVS data in Table 3, the GLDV in this study complies with Euro 5 regulations. Furthermore, emission of regulated compounds is close to those previously observed from a Euro 5 GLDV during the NEDC cycle (EC, 2010, and Internal Communication, Joint Research Centre) as well as from a Euro 4 GLDV tested during different driving cycles (Chirico et al., 2013).

Table 4 shows EFs for carbonaceous aerosol from the GLDV. Black carbon (BC) emission factors were calculated using aethalometer data, presented in Fig. S2. Values $\mathrm{EF}_{\text {MASS }}=20.0 \times 10^{-3}$ and $11.2 \times 10^{-3} \mathrm{~g} \mathrm{BC} \mathrm{kg}^{-1}$ were obtained for Exp. 1 and 2, respectively. A higher value, $\mathrm{EF}_{\mathrm{MASS}}$ of $52.5 \times 10^{-3} \mathrm{~g} \mathrm{BC} \mathrm{kg}^{-1}$ fuel, is used in the emission inventory of Bond et al. (2004), for regions, e.g. United States and Europe, where relatively stringent emissions controls were in place as of 2004. This is consistent with the adoption of emissions controls and newer engine technology subsequent to 2004, e.g. Euro 4 in 2005 and Euro 5 in 2008. As expected, $\mathrm{BC}$ emissions for the GLDV were much lower than those observed for a diesel light-duty vehicle (Chirico et al., 2010), Fig. 8, black. The Ångström exponent $(\alpha)$, a standardised parameter describing the decrease in light absorbance with 
Table 3. Emission factors for regulated compounds calculated for a Euro 5 gasoline light-duty vehicle from smog chamber data and VELA (CVS) data, averaged over two experiments, and Euro 5 limit values for gasoline light-duty vehicles. For smog chamber data, the range of observed values, lowest-highest, is given.

\begin{tabular}{|c|c|c|c|c|}
\hline & $\mathrm{CO}$ & $\mathrm{THC}$ & NMHC & $\mathrm{NO}_{\mathrm{x}}$ \\
\hline \multicolumn{5}{|c|}{ From smog chamber data } \\
\hline $\mathrm{EF}_{\text {MASS }}\left(\mathrm{g} \mathrm{kg}^{-1}\right.$ fuel $)$ & $12.69-13.87$ & $0.91-1.06$ & $0.77-0.86$ & $0.72-1.06$ \\
\hline $\mathrm{EF}_{\mathrm{KM}}\left(\mathrm{g} \mathrm{km}^{-1}\right)$ & $0.50-0.55$ & $0.036-0.042$ & $0.030-0.034$ & $0.028-0.041$ \\
\hline \multicolumn{5}{|c|}{ From CVS data } \\
\hline $\mathrm{EF}_{\text {MASS }}\left(\mathrm{g} \mathrm{kg}^{-1}\right.$ fuel $)$ & $18.84 \pm 0.68$ & $1.75 \pm 0.21$ & $1.75 \pm 0.21$ & $0.89 \pm 0.14$ \\
\hline $\mathrm{EF}_{\mathrm{KM}}\left(\mathrm{g} \mathrm{km}^{-1}\right)$ & $0.741 \pm 0.03$ & $0.069 \pm 0.009$ & $0.069 \pm 0.009$ & $0.035 \pm 0.005$ \\
\hline \multicolumn{5}{|c|}{ Euro 5 limit values for GLDVs } \\
\hline $\mathrm{EF}_{\mathrm{KM}}\left(\mathrm{g} \mathrm{km}^{-1}\right)$ & 1.000 & 0.100 & 0.068 & 0.060 \\
\hline
\end{tabular}

Table 4. Range of emission factors for carbonaceous aerosol and secondary organic aerosol formation for a Euro 5 gasoline light-duty vehicle calculated from smog chamber data and particulate matter (PM) from VELA (CVS) data. The range of observed values is given.

\begin{tabular}{|c|c|c|c|c|}
\hline Emission factor $(\mathrm{EF})$ & $\begin{array}{l}\text { Black carbon } \\
(\mathrm{BC}) \times 10^{-3}\end{array}$ & $\begin{array}{l}\text { Primary organic } \\
\text { aerosol (POA) } \\
\times 10^{-3}\end{array}$ & $\begin{array}{l}\text { Total primary } \\
(\mathrm{BC}+\mathrm{POA}) \times 10^{-3}\end{array}$ & $\begin{array}{l}\text { Secondary organic } \\
\text { aerosol formation } \\
(\mathrm{SOA}) \times 10^{-3}\end{array}$ \\
\hline \multicolumn{5}{|c|}{ From smog chamber data } \\
\hline $\mathrm{EF}_{\text {MASS }}\left(\mathrm{g} \mathrm{kg}^{-1}\right.$ fuel $)$ & $11.2-20.0$ & $24.5 \pm 19.7$ & $25.8-40.5$ & $344-347$ \\
\hline $\mathrm{EF}_{\mathrm{KM}}\left(\mathrm{g} \mathrm{km}^{-1}\right)$ & $1.2-1.7$ & $0.4-1.4$ & $1.0-2.2$ & $12.2-13.2$ \\
\hline \multicolumn{5}{|c|}{ From CVS data } \\
\hline $\mathrm{EF}_{\mathrm{KM}}\left(\mathrm{g} \mathrm{km}^{-1}\right)$ & NA & NA & $1.1-1.7$ & NA \\
\hline
\end{tabular}

respect to wavelength for $\mathrm{BC}$, and a useful tool for source apportionment (Sandradewi et al., 2008) is also shown in Fig. S2 for Exp. 2. The initial value of 1.2 was obtained for aerosols from the gasoline car, which is higher than values reported for diesel cars (Sandradewi, 2008, and references therein). A slow reduction of $\alpha$ during the experiment was observed, except immediately after the UV light switch-on, where a transient increase of $\alpha$ is observed. These changes could be caused by an increase of coating thickness due to condensation or evaporation, and oxidation of the adsorbed species.

As Fig. 8 shows, POA emissions from the GLDV are lower than those previously reported for a Euro 3 diesel vehicle equipped with an oxidation catalyst, but no diesel particle filter (DPF) (Chirico et al., 2010). An alternative, gravimetric measurement of primary PM measured from the CVS is also reported in Table 4. PM emission factors are close to the combined $\mathrm{OA}+\mathrm{BC}$ taken from the chamber (see Fig. S3), suggesting that there are only small errors in the reported primary emission factors. Small variation in the methodologies likely results from a number of factors including, but not limited to, (i) adsorption artefacts on the filters, (ii) effects due to lower-than-smog chamber dilution in the CVS, (iii) error in the aethalometer estimation of $\mathrm{BC}$, and (iv) error in the SMPS measurement due to differences in effective and mobility diameters. A high-resolution AMS mass spectrum of the POA from Exp. 2 is presented in Fig. 9. POA emissions are highly hydrocarbon like, containing very few oxidised fragments.

Measurements of the average THC concentration in the raw exhaust vs. those in the chamber could be also used to quantify VOC losses in the sampling system of the mobile chamber. Chirico et al. (2010) suggest that SOA formation is unaffected by sampling line temperature over the range of $80-150^{\circ} \mathrm{C}$, since an aerosol sample will respond dynamically to changes in temperature and concentration. That is, upon entering the smog chamber, emitted particles will partition as though in the atmosphere, regardless of temperature and concentration in the sampling system itself. However, SOA formation may also be influenced by the loss of gaseous precursors in the emission sampling lines. Assuming no loss of inert $\mathrm{CO}_{2}$ in the system, the fraction of $\mathrm{THC}$ lost in the sampling lines can be estimated:

$\mathrm{THC}$ lost $=1-\left(\frac{\Delta \mathrm{THC}_{\text {Chamber }} / \overline{\mathrm{THC}}_{\text {Exhaust }}}{\Delta \mathrm{CO}_{2 \text { Exhaust } / \overline{\mathrm{CO}}_{2 \text { Exhaust }}}}\right)$, 
Table 5. Predicted gas phase photolysis rates of selected compounds in the mobile smog chamber at $25^{\circ} \mathrm{C}$ and $-7^{\circ} \mathrm{C}$.

\begin{tabular}{|c|c|c|c|c|}
\hline \multirow[t]{2}{*}{ Compound } & \multirow[t]{2}{*}{ Reaction } & \multicolumn{2}{|c|}{$\begin{array}{c}J_{i} \\
\left(10^{-5} \mathrm{~s}^{-1}\right)\end{array}$} & \multirow[t]{2}{*}{$\begin{array}{c}\text { Ratio } \\
J_{i,-7^{\circ} \mathrm{C}} / J_{i, 25^{\circ} \mathrm{C}}\end{array}$} \\
\hline & & $25^{\circ} \mathrm{C}$ & $-7^{\circ} \mathrm{C}$ & \\
\hline Nitrogen dioxide & $\mathrm{NO}_{2}>\mathrm{NO}+\mathrm{O}\left({ }^{3} \mathrm{P}\right)$ & 797 & 259 & 0.32 \\
\hline Ozone & $\mathrm{O}_{3}>\mathrm{O}\left({ }^{1} \mathrm{D}\right)$ & 43.1 & 17.8 & 0.41 \\
\hline Nitrous acid & $\mathrm{HONO}>\mathrm{OH}+\mathrm{NO}$ & 214 & 68.4 & 0.32 \\
\hline \multirow[t]{2}{*}{ Nitrate } & $\mathrm{NO}_{3}>\mathrm{NO}+\mathrm{O}_{2}$ & 0.00 & 0.00 & - \\
\hline & $\mathrm{NO}_{3}>\mathrm{NO}_{2}+\mathrm{O}\left({ }^{3} \mathrm{P}\right)$ & 444 & 135 & 0.30 \\
\hline \multirow[t]{2}{*}{ Formaldehyde } & $\mathrm{HCHO}>\mathrm{HCO}+\mathrm{H}$ & 1.50 & 0.53 & 0.36 \\
\hline & $\mathrm{HCHO}>\mathrm{CO}+\mathrm{H}_{2}$ & 3.74 & 1.35 & 0.36 \\
\hline Acetaldehyde & $\mathrm{CH}_{3} \mathrm{CHO}>$ products & 0.11 & - & - \\
\hline Methyl hydroperoxide. & $\mathrm{CH}_{3} \mathrm{OOH}>$ products & 0.43 & - & - \\
\hline Glyoxal & $(\mathrm{CHO})_{2}>$ products & 0.71 & - & - \\
\hline Methyl vinyl ketone & $\mathrm{CH}_{3} \mathrm{C}(\mathrm{O}) \mathrm{CH}=\mathrm{CH}_{2}>$ products & 0.34 & - & - \\
\hline Acetone & $\mathrm{CH}_{3} \mathrm{C}(\mathrm{O}) \mathrm{CH}_{3}>$ products & 0.01 & - & - \\
\hline Methyl nitrate & $\mathrm{CH}_{3} \mathrm{ONO}_{2}>$ products & 0.29 & - & - \\
\hline Peroxy acetyl nitrate (PAN) & $\mathrm{CH}_{3} \mathrm{C}(\mathrm{O}) \mathrm{OONO}_{2}>$ products & 0.04 & - & - \\
\hline
\end{tabular}

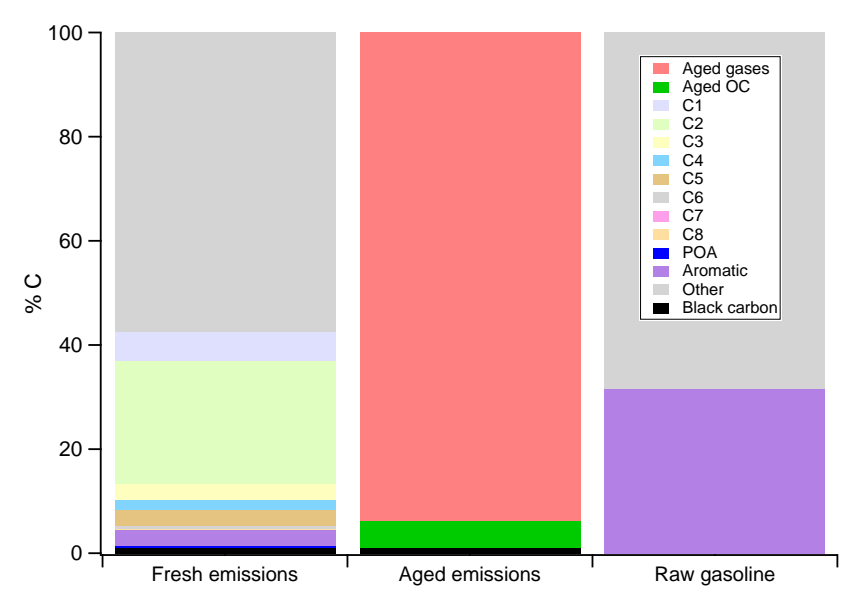

Fig. 7. Composition of fresh and smog chamber aged exhaust emissions $\left(\mathrm{CO}_{2}\right.$ normalised) from a Euro 5 gasoline light-duty vehicle (Exp. 2), and raw gasoline fuel. Data are presented as a carbon mass balance. The following species were included: $\mathrm{C} 1$ : methane and formaldehyde; $\mathrm{C} 2$ : ethane, acetylene and ethane; $\mathrm{C} 3$ : propane and propene; $\mathrm{C} 4$ : isobutane, n-butane, trans-2-butene, 1-butene, cis-2butene, and 1,3-butadiene; C5: 2-methylbutane, n-pentane, trans-2pentene, 1-pentene, and isoprene; C6: 2-methylpentane and hexane; C7: n-heptane; C8: 2,2,4-trimethylpentane and n-octane.

where $\triangle \mathrm{THC}_{\mathrm{Chamber}}$ and $\Delta \mathrm{CO}_{2}$ Chamber denotes the change in THC and $\mathrm{CO}_{2}$ concentration measured in the smog chamber, respectively, and $\overline{\mathrm{THC}}_{\text {Exhaust }}$ and $\overline{\mathrm{CO}}_{2 \text { Exhaust }}$ are the average exhaust concentrations of THC and $\mathrm{CO}_{2}$ measured using the FTIR. Note that these average concentrations used for Eq. 8 are taken directly from the tailpipe, not the from CVS data which are reported as emission factors. $\mathrm{CO}_{2}$ in Eq. (8) can also be replaced with other tracers, such as NO, also measured from both smog chamber and using VELA instrumentation. Using this methodology an average THC loss of $20 \%$ was determined, with both $\mathrm{NO}$ and $\mathrm{CO}_{2}$ as tracers giving the same result. This calculated loss encompasses instrument error (two different instruments were used for each gas, one sampling from the chamber and one from the CVS), losses in instrument sampling lines, the effect of different measurement location (CVS in the VELA vs. smog chamber), losses to the chamber walls as well as losses in the exhaust sampling lines. Such losses appear minor, although depending on which individual VOCs, i.e. whether SOA precursors are lost, and to what extent, a small underestimation of SOA production is possible.

\subsubsection{Secondary organic aerosol formation and aging}

Aging of the GLDV emissions resulted in significant SOA formation (Fig. 8) during both experiments, around $340 \times 10^{-3} \mathrm{~g} \mathrm{~kg}^{-1}$ fuel (Table 3). Thus for this gasoline car SOA is the dominant fraction (9-15 times higher than the POA) of emitted or formed aerosol pollution after a relatively short time in the ambient atmosphere. This is consistent with recent results on idling emissions from older gasoline vehicle emissions reported by Nordin et al. (2013). Furthermore, this SOA was formed after an $\mathrm{OH}$ exposure equivalent to approximately $12 \mathrm{~h}$ of ambient aging (assuming a $24 \mathrm{~h}$ ambient mean $\mathrm{OH}$ concentration of $10^{6} \mathrm{~cm}^{-3}$ ), indicating that SOA formation occurs rapidly in the atmosphere. This result is consistent with a recent ambient study which concludes that gasoline SOA is the largest source of vehicular carbonaceous PM in the Los Angeles basin (Bahreini et al., 2012), again 


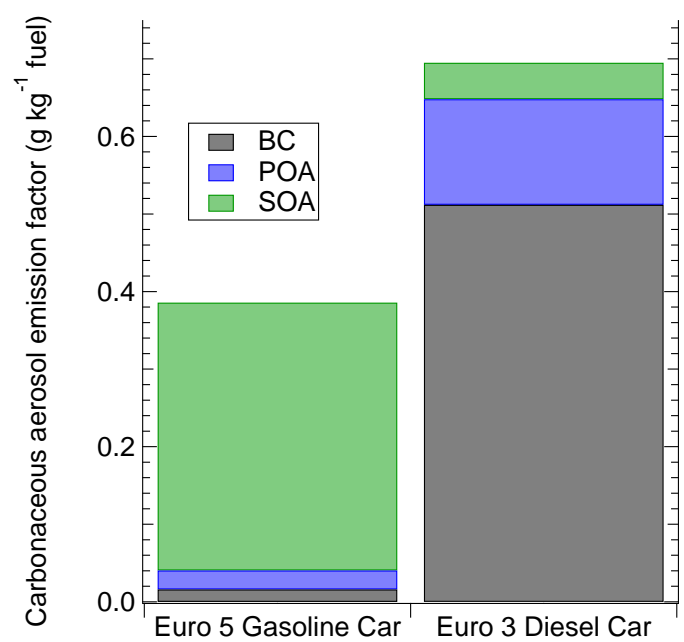

Fig. 8. Primary aerosol emission factors and secondary organic aerosol formation factors calculated for the Euro 5 gasoline lightduty vehicle (GLDV) (average over experiments 1 and 2) of this study and the results of a previous smog chamber study on a Euro 3 diesel passenger car (with oxidation catalyst, but without diesel particle filter, DPF) by Chirico et al. (2010). The diesel emissions are dominated by black carbon (BC, black) and primary organic aerosol (POA, blue) with only a small secondary organic aerosol (SOA, green) fraction. Conversely, a large fraction of the GLDV emission comprises SOA after aging. The large SOA fraction for the GLDV suggests a larger contribution from gasoline vehicles to ambient particulate pollution than has so far been recognised based on primary emissions. Further, future use of DPFs would remove almost all of the primary BC and POA emissions from diesel vehicle emissions, in which case the total particulate emissions (i.e. POA + SOA) for the GLDV may exceed those of a diesel vehicle. It should be noted that smog chamber OA concentrations in the Chirico et al. (2010) study were lower $\left(<30 \mu \mathrm{g} \mathrm{m}^{-3}\right)$ than those in this study, leading to lower emission factors due to lower partitioning to the aerosol phase.

suggesting that other gasoline cars may behave similarly to this vehicle.

SOA represents only a modest mass fraction of the total aged aerosol for the diesel vehicle, from a smog chamber study by Chirico et al. (2010), shown in Fig. 8, green. The average factor increase in mass due to aging was 12.0 and 1.3 for the gasoline and diesel vehicle, respectively. Similarly, Robinson et al. (2007) report a factor of around 1.7 increase in mass due to aging $\left(\mathrm{OH}=2 \times 10^{6}\right.$ molecules $\left.\mathrm{cm}^{-3}\right)$ from diesel emissions. Note that the smog chamber concentrations in this study are a factor of 7 higher than in Chirico et al. (2010). This would likely result in larger partitioning to the particle phase and an increase in SOA mass. An estimation of this effect can be made using high $\mathrm{NO}_{\mathrm{x}}$ yield curves (Ng et al., 2007) for xylene, where SOA yields are only a factor of 1.3-1.4 higher at $200 \mu \mathrm{g} \mathrm{m}^{-3}$ compared to $30 \mu \mathrm{g} \mathrm{m}^{-3}$. Therefore even at lower concentrations, SOA formation can be expected to be significantly higher for this gasoline vehicle than for the diesel of Chirico et al. (2010).

This difference in emissions profile after aging may be largely explained in terms of differences in the magnitude of THC emissions, which are typically higher for modern gasoline than for diesel vehicles. The average THC emission in this study (smog chamber data) was $40 \mathrm{mg} \mathrm{km}^{-1}$, while a value of $96.5 \mathrm{mg} \mathrm{km}^{-1}$ has also been reported for a Euro 5 GLDV from an NEDC cycle (EC, 2010). Diesel engines operate under lean conditions with a higher air/fuel ratio in comparison to the spark ignition engines typically used by GLDVs. For this reason, diesel engine exhaust contains less THC than gasoline vehicles without catalysts (10-100 times less, Schmitz et al. (2000), as well as less CO and typically higher $\mathrm{NO}_{\mathrm{x}}$ ).

The impact of diesel vehicles on ambient PM concentrations may further decrease in Europe where meeting emissions regulations will necessitate the use of DPFs on new vehicles. For example, light-duty diesel vehicles require a DPF in order to reach Euro 5 onwards, while heavy duty diesel vehicles are expected to require DPFs in order to meet Euro VI legislation (Johnson, 2008). A DPF has close to $100 \%$ efficiency in terms of particle mass when used correctly. However, the potential use of a gasoline particle filter (GPF) in gasoline vehicles would be ineffective at reducing hydrocarbon emissions which may lead to SOA formation. Indicated in Fig. 5 is the $\mathrm{O}: \mathrm{C}$ ratio of the POA and of the aged $\mathrm{OA}$, which increase with time and $\mathrm{OH}$ exposure in the chamber. Normalised high-resolution mass spectra of the fresh (primary) and aged aerosol for Exp. 2 are also shown in Fig. 9. An increasing $\mathrm{O}: \mathrm{C}$, reflecting increasing oxygen content following oxidisation, is predicted by theory (Jimenez et al., 2009) and has been observed in ambient datasets ( $\mathrm{Ng}$ et al., 2010). Highly aged ambient aerosols typically have O : C ratios approaching unity, whereas urban combustion related aerosol have been observed in the range 0.06-0.1 (Aiken et al., 2008). The $\mathrm{O}: \mathrm{C}$ ratio of 0.7 observed here is the same as that of the ambient observed low volatility oxygenated organic aerosol (LV-OOA) (Ng et al., 2010). This increase is observed during both experiments at similar $\mathrm{OH}$ exposures as ambient under conditions (Aiken et al., 2008). Previous smog chamber studies, performed at similar PM concentrations to those here, on a wide range of emissions from wood burning (Heringa et al., 2011) to biogenic SOA precursors (Ng et al., 2010; Pfaffenberger et al., 2013), could not often reproduce such an $\mathrm{O}: \mathrm{C}$ increase (values below 0.5 are typically reported). Recent aging experiments by Nordin et al. (2013) on the aging of emissions from older Euro 2-4 idling gasoline cars also produce SOA with lower $\mathrm{O}: \mathrm{C}(\sim 0.4)$ than observed in this study. This suggests that the emissions of this Euro 5 car operated under the conditions of this study have a unique VOC profile, which yield upon oxidation high amounts of highly oxidised SOA. Generally, long-chain hydrocarbons with many oxygen atoms are thermodynamically unstable, while highly oxidised aerosol is more likely to be 

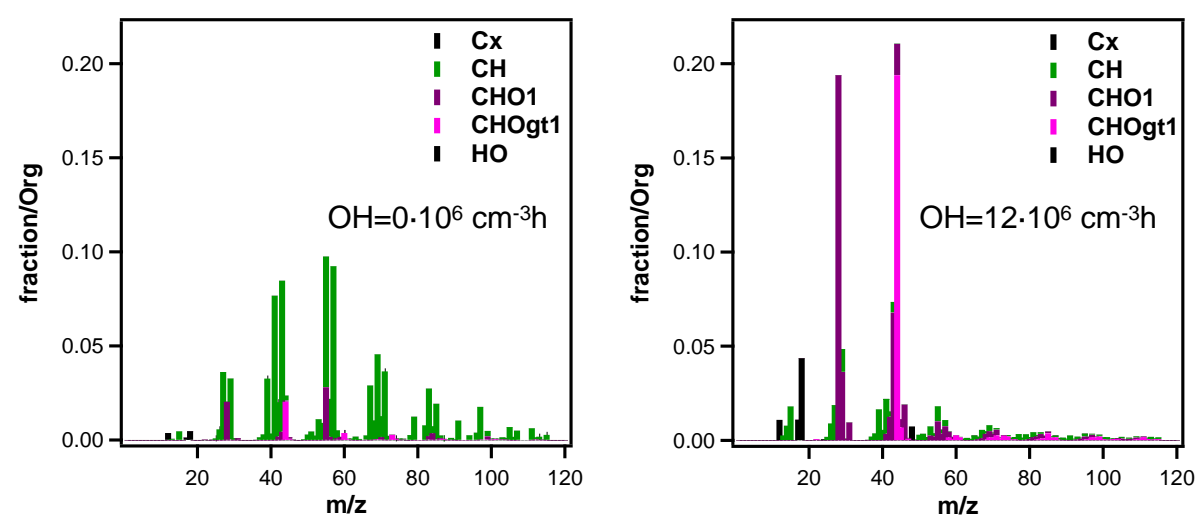

Fig. 9. High-resolution aerosol mass spectra measured at the mobile smog chamber of fresh primary and aged emission at an $\mathrm{OH}$ exposure of $12 \times 10^{6} \mathrm{~cm}^{-3} \mathrm{~h}$ from a gasoline light-duty vehicle.

produced in fewer generations from smaller precursor hydrocarbons (Kroll et al., 2011). Therefore, this suggests that the remarkably high $\mathrm{O}: \mathrm{C}$ ratio here results from the oxidation and condensation of smaller, unknown SOA precursor hydrocarbons or processes.

\subsubsection{Secondary organic aerosol yields}

A SOA yield $Y$ is defined as

$Y=\frac{\Delta \mathrm{OA}}{\Delta \mathrm{VOC}}$,

where $\triangle \mathrm{OA}$ is the aerosol produced for a given change in reactive hydrocarbon concentration $\triangle \mathrm{VOC}$. Unfortunately, information on how much of initial hydrocarbon emission has reacted inside the smog chamber to produce SOA during this study is not available; the THC analyser does not discriminate between the initial VOC and gas phase reaction products. However, Fig. 7 indicates that despite significant SOA production, only around $5 \%$ of emitted VOC and particle phase carbon condenses to the particle phase. That is, a large SOA yield is not required in order to account for the SOA production observed from this vehicle.

An estimated maximum SOA production $\left(\triangle \mathrm{OA}_{\text {predicted }}\right)$ from light aromatic hydrocarbons in the emissions (benzene, toluene, C2-benzenes, C3-benzenes or naphthalene) can be determined using

$\Delta \mathrm{OA}_{\text {predicted }}=\sum_{i}\left(\Delta_{i} \times Y_{i}\right)$,

where $\Delta_{i}$ is the change in concentration of an aromatic hydrocarbon $i$, measured from the smog chamber using PTRToF-MS, and $\mathrm{Y}_{i}$ is the low $\mathrm{NO}_{\mathrm{x}}$ SOA yield of aromatic $i$. SOA yields for benzene, toluene, and $m$-xylene $(\sim 0.3)$ are taken from $\mathrm{Ng}$ et al. (2007). The low $\mathrm{NO}_{\mathrm{x}} \mathrm{SOA}$ yield for $m$ xylene is used for all $\mathrm{C} 2$ and $\mathrm{C} 3$ benzenes, while the SOA yield for naphthalene (0.73) is taken from Chan et al. (2009). Low $\mathrm{NO}_{\mathrm{x}}$ yields are used since these are higher than high

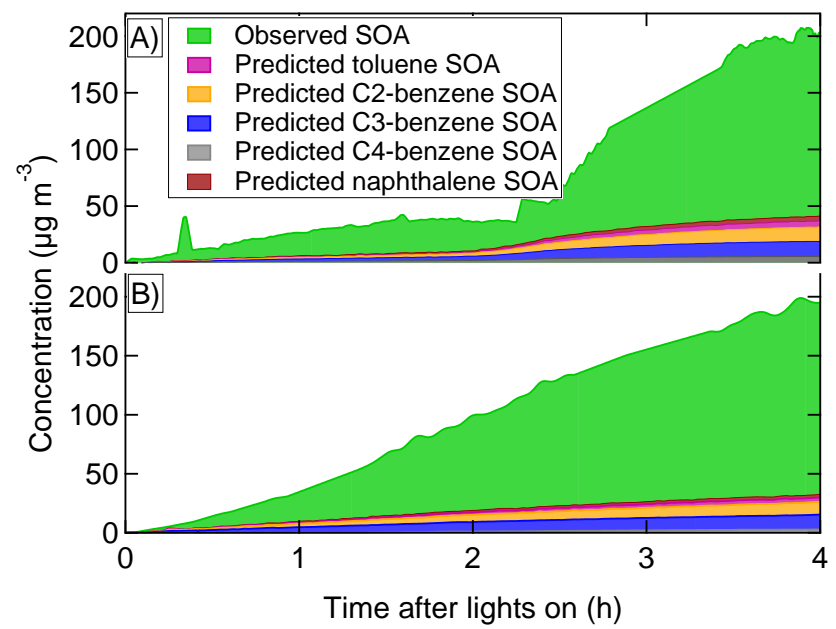

Fig. 10. Observed secondary organic aerosol (SOA) formation, wall loss corrected, green, in the mobile smog chamber during aging of emissions from a Euro 5 gasoline light-duty vehicle and predicted SOA formation based on measurement of aromatic hydrocarbon decay for Exp. 1 (A) and Exp. 2 (B). Low $\mathrm{NO}_{\mathrm{x}}$ yields are used to predict SOA from the aromatics in order to provide an upper limit. Only a small fraction of observed SOA is explained by the oxidation of aromatic hydrocarbons.

$\mathrm{NO}_{\mathrm{x}}$ yields, thereby allowing a maximum estimation. Fig. 10 shows that, using this methodology $\triangle \mathrm{OA}_{\text {predicted accounts }}$ for $<20 \%$ of the observed SOA production. Candidate nonaromatic (unknown) precursors may include smaller, highly oxygenated hydrocarbons, as suggested by the high $\mathrm{O}: \mathrm{C}$ ratio of the aged OA (see Sect. 3.2.2, above). Odum et al. (1997) assume that the composition of gasoline vehicle exhaust matches that of raw gasoline and suggest that SOA formation from gasoline vehicle emissions may be accounted for by aromatic oxidation. However, Fig. 7 shows that although there would be enough aromatic hydrocarbons in the raw fuel to produce the SOA observed here while only requiring modest SOA yields, the VOC composition of the exhaust 
is significantly different to that of raw gasoline. Strikingly, the total carbon content of the aged OA is actually higher than the total carbon emitted as light aromatic hydrocarbons. This demonstrates that, at least in the case of this vehicle, aromatics in raw gasoline cannot be used to account for SOA production. This result is consistent with previous vehicle emission aging studies (Robinson et al., 2007; Grieshop et al., 2009). However, these results contradict Nordin et al. (2013), who suggest that around $60 \%$ of SOA may be explained by aromatic oxidation. This may be a consequence of the different methodology employed,; Nordin et al. (2013) used older test vehicles which were operated under engine idling and relatively low temperature (ambient, outdoor). This suggests an influence of driving conditions on SOA formation. To understand and quantify SOA formation from vehicles, emissions generated under controlled, repeatable, and as realistic as possible conditions may be required.

\section{Conclusions}

We have shown that the new Paul Scherrer Institute mobile environmental reaction chamber can be of considerable utility in atmospheric science. Due to the flexible design of the chamber, a wide range of emissions aging or ambient studies are possible with a single facility. We have characterised the mobile smog chamber and demonstrated its utility and potential with results from measurements at a specialised testing facility, the European Commission Joint Research Centre (JRC).

We have demonstrated that a modern gasoline car can produce significantly higher secondary aerosol than the emitted primary (up to 15 times). This is consistent with very recent emission and ambient studies (Bahreini et al., 2012; Nordin et al., 2013) and has not previously been observed for tailpipe emissions from diesel vehicles. Furthermore, gasoline vehicle SOA appears in this case to be highly oxygenated, formed from unknown precursors or mechanisms.

So far no experimental data, other than those here, have been published on SOA formation from gasoline vehicles operated the under controlled, repeatable conditions offered by a dedicated vehicle testing facility. Ultimately however, more work is needed to study real tailpipe emissions from more vehicles than the single car presented in this study, especially as SOA formation under experimental conditions may be highly variable, varying with background OA concentration and $\mathrm{VOC} / \mathrm{NO}_{\mathrm{x}}$ levels.

Furthermore, given that real tailpipe emissions can be significantly different to raw gasoline, and that emissions likely vary according to driving conditions, future studies should aim to replicate real-world driving as closely as possible in order to better estimate and understand SOA formation from vehicles.

\section{Supplementary material related to this article is available online at: http://www.atmos-chem-phys.net/13/ 9141/2013/acp-13-9141-2013-supplement.pdf.}

Acknowledgements. This work was supported by the Swiss Federal Office for the Environment (FOEN), the Federal Roads Office (FEDRO), the Swiss National Science Foundation (SNSF) for SAPMAV (No. 200021_13016) and Ambizione (NF-BBB-A), and The French Environment and Energy Management Agency (ADEME, Grant number 1162C00O2), EUROSTARS grant E!4825 FC Aeth and JR-KROP grant 3211-11-000519. Operation part-financed by the European Union, European Social Fund.

The VELA staff is acknowledged for its skilful technical assistance, in particular Franz Muehlberger, Urbano Manfredi, and Philippe Le Lijours.

We appreciate the insights into the details of the Carnegie Mellon mobile chamber and would like to thank the whole group of Allen Robinson and especially Albert Presto.

Edited by: N. M. Donahue

\section{References}

Aiken, A. C., DeCarlo, P. F., Kroll, J. H., Worsnop, D. R., Huffman, J. A., Docherty, K. S., Ulbrich, I. M., Mohr, C., Kimmel, J. R., Sueper, D., Sun, J. Y., Zhang, Q., Trimborn, A., Northway, M. J., Ziemann, P. J., Canagaratna, M., Onasch, T. B., Alfarra, M. R., Prevot, A. S. H., Dommen, J., Duplissy, J., Metzger, A., Baltensperger, U., and Jimenez, J. L.: O/C and OM/OC ratios of primary, secondary, and ambient organic aerosols with high-resolution time-of-flight aerosol mass spectrometry, Environ. Sci. Technol., 42, 4478-4485, 2008.

Atkinson, R., Baulch, D. L., Cox, R. A., Crowley, J. N., Hampson, R. F., Hynes, R. G., Jenkin, M. E., Rossi, M. J., and Troe, J.: Evaluated kinetic and photochemical data for atmospheric chemistry: Volume $\mathrm{I}-$ gas phase reactions of $\mathrm{O}_{\mathrm{x}}, \mathrm{HO}_{\mathrm{x}}, \mathrm{NO}_{\mathrm{x}}$ and $\mathrm{SO}_{\mathrm{x}}$ species, Atmos. Chem. Phys., 4, 1461-1738, doi:10.5194/acp-41461-2004, 2004.

Atkinson, R., Baulch, D. L., Cox, R. A., Crowley, J. N., Hampson, R. F., Hynes, R. G., Jenkin, M. E., Rossi, M. J., Troe, J., and others: Evaluated kinetic and photochemical data for atmospheric chemistry: Volume II: gas phase reactions of organic species, Atmospheric Chemistry and Physics, 6, 3625-4055, 2006.

Bahreini, R., Middlebrook, A. M., de Gouw, J. A., Warneke, C., Trainer, M., Brock, C. A., Stark, H., Brown, S. S., Dube, W. P., Gilman, J. B., and others: Gasoline emissions dominate over diesel in formation of secondary organic aerosol mass, Geophys. Res. Lett., 39, L06805, doi:10.1029/2011GL050718, 2012.

Barlow, T. J., Latham, S., McCrae, P. G., and Boulter, P. G.: A reference book of driving cycles for use in the measurement of road vehicle emissions (2009), United Kingdom Transport Research Laboratory (TRL), http://www.trl.co.uk/online_store/ reports_publications/trl_reports/cat_traffic_and_the_environment/ report_a_reference_book_of_driving_cycles_for_use_in_the_ measurement_of_road_vehicle_emissions.htm, (last access: 2 May 2012), 2009. 
Barmet, P., Dommen, J., DeCarlo, P. F., Tritscher, T., Praplan, A. P., Platt, S. M., Prévôt, A. S. H., Donahue, N. M., and Baltensperger, U.: $\mathrm{OH}$ clock determination by proton transfer reaction mass spectrometry at an environmental chamber, Atmos. Meas. Tech., 5, 647-656, doi:10.5194/amt-5-647-2012, 2012.

Bond, T. C., Streets, D. G., Yarber, K. F., Nelson, S. M., Woo, J. H., and Klimont, Z.: A technology-based global inventory of black and organic carbon emissions from combustion, J. Geophys. Res. Lett., 109, D14203, doi:10.1029/2003JD003697, 2004.

Carter, W. P. L.: National Renewable Energy Laboratory (US), Environmental chamber studies of atmospheric reactivities of volatile organic compounds: Effects of varying chamber and light source, Statewide Air Pollution Research Center, 1995.

Chan, A. W. H., Kautzman, K. E., Chhabra, P. S., Surratt, J. D., Chan, M. N., Crounse, J. D., Kürten, A., Wennberg, P. O., Flagan, R. C., and Seinfeld, J. H.: Secondary organic aerosol formation from photooxidation of naphthalene and alkylnaphthalenes: implications for oxidation of intermediate volatility organic compounds (IVOCs), Atmos. Chem. Phys., 9, 3049-3060, doi:10.5194/acp-9-3049-2009, 2009.

Chirico, R., DeCarlo, P. F., Heringa, M. F., Tritscher, T., Richter, R., Prévôt, A. S. H., Dommen, J., Weingartner, E., Wehrle, G., Gysel, M., Laborde, M., and Baltensperger, U.: Impact of aftertreatment devices on primary emissions and secondary organic aerosol formation potential from in-use diesel vehicles: results from smog chamber experiments, Atmos. Chem. Phys., 10, 11545-11563, doi:10.5194/acp-10-11545-2010, 2010.

Chirico, R., Clairotte, M., Adam, T. W., Giechaskiel, B., Heringa, M. F., Elasser, M., Martini, G., Manfredi, U., DeCarlo, P. F., Streibel, T., Sklorz, M., Zimmermann, R. A., C., Baltensperger, U., and Prévôt, A. S. H.: Chassis dynamometer measurements of organic mass, black carbon, particle number, and regulated and unregulated gas emissions from scooters and light and heavy duty vehicles, in preparation, 2013.

Clairotte, M., Adam, T. W., Chirico, R., Giechaskiel, B., Manfredi, U., Elsasser, M., Sklorz, M., DeCarlo, P. F., Heringa, M. F., Zimmermann, R., Martini, G., krasenbrink, A., Vicet, A., Tournie, E., Prevot, A. S. H., and Astorga, C.: Online Characterization of Regulated and Unregulated Gaseous and Particulate Exhaust Emission from Two-Stroke Mopeds: A Chemometric Approach, Anal. Chim. Acta, 44, 505-512, 2011.

DeCarlo, P. F., Kimmel, J. R., Trimborn, A., Northway, M. J., Jayne, J. T., Aiken, A. C., Gonin, M., Fuhrer, K., Horvath, T., Docherty, K. S., Worsnop, D. R., and Jimenez, J. L.: Field-deployable, high-resolution, time-of-flight aerosol mass spectrometer, Anal. Chem., 78, 8281-8289, 2006.

Dockery, D. W. and Pope, C. A.: Acute respiratory effects of particulate air pollution, Ann. Rev. Pub. Health, 15, 107-132, 1994.

Dockery, D. W., Pope, C. A., Xu, X., Spengler, J. D., Ware, J. H., Fay, M. E., Ferris Jr, B. G., and Speizer, F. E.: An association between air pollution and mortality in six US cities, New Engl. J. Med., 329, 1753-1759, 1993.

Donahue, N. M., Robinson, A. L., Stanier, C. O., and Pandis, S. N.: Coupled partitioning, dilution, and chemical aging of semivolatile organics, Environ. Sci. Technol., 40, 2635-2643, 2006.

Donahue, N. M., Henry, K. M., Mentel, T. F., Kiendler-Scharr, A., Spindler, C., Bohn, B., Brauers, T., Dorn, H. P., Fuchs, H., Tillmann, R., Wahner, A., Saathoff, H., Naumann, K.-H., Moehler,
O., Leisner, T., Mueller, L., Reinnig, M.-C., Hoffmann, T., Salo, K., Hallquist, M., Frosch, M., Bilde, M., Tritscher, T., Barmet, P., Praplan, A. P., DeCarlo, P. F., Dommen, J., Prevot, A. S. H., and Baltensperger, U.: Aging of Secondary Organic Aerosol via Gas-Phase OH Radical Reactions, Proc. Natl. Acad. Sci. USA, 109, 13503-13508, 2012.

EEA: EMEP/ CORINAIR Emission Inventory Guidebook, European Environment Agency, http://reports.ee.europa.eu/ EMEPCORINAIR4 (last access: 2 May 2012), Technical Report 11/2006, 2006.

EC: European Commission Regulation No 692/2008 of 18 July 2008 implementing and amending Regulation (EC) No 715/2007 of the European Parliament and of the Council on type-approval of motor vehicles with respect to emissions from light passenger and commercial vehicles (Euro 5 and Euro 6) and on access to vehicle repair and maintenance information., Official Journal of the European Communities, L199, 2008.

EC: Regulated emissions of a Euro 5 passenger car measured over different driving cycles, European Commission Joint Research Centre (JRC) Institute for Environment and Sustainability, http://www.unece.org/fileadmin/DAM/trans/doc/ 2010/wp29grpe/WLTP-DHC-04-03e.pdf (last access: 9 July 2012), 2010.

EEC: The Council of the European Communities. Council Directive 70/220/EEC of 20 March 1970 on the approximation of the laws of the Member States relating to measures to be taken against air pollution by gases from positive-ignition engines of motor vehicles, Official Journal of the European Communities, L076, 1-22, 1970.

Gentner, D. R., Isaacman, G., Worton, D. R., Chan, A. W. H., Dallmann, T. R., Davis, L., Liu, S., Day, D. A., Russell, L. M., Wilson, K. R., and others: Elucidating secondary organic aerosol from diesel and gasoline vehicles through detailed characterization of organic carbon emissions, Proc. Natl. Acad. Sci., 109, 18318-18323, 2012.

Graus, M., Müller, M., and Hansel, A.: High Resolution PTR-TOF: Quantification and Formula Confirmation of VOC in Real Time, J. Am. Soc. Mass Spectrom., 1037-1044, 2010.

Grieshop, A. P., Logue, J. M., Donahue, N. M., and Robinson, A. L.: Laboratory investigation of photochemical oxidation of organic aerosol from wood fires 1: measurement and simulation of organic aerosol evolution, Atmos. Chem. Phys., 9, 1263-1277, doi:10.5194/acp-9-1263-2009, 2009.

Hallquist, M., Wenger, J. C., Baltensperger, U., Rudich, Y., Simpson, D., Claeys, M., Dommen, J., Donahue, N. M., George, C., Goldstein, A. H., Hamilton, J. F., Herrmann, H., Hoffmann, T., Iinuma, Y., Jang, M., Jenkin, M. E., Jimenez, J. L., Kiendler-Scharr, A., Maenhaut, W., McFiggans, G., Mentel, Th. F., Monod, A., Prévôt, A. S. H., Seinfeld, J. H., Surratt, J. D., Szmigielski, R., and Wildt, J.: The formation, properties and impact of secondary organic aerosol: current and emerging issues, Atmos. Chem. Phys., 9, 5155-5236, doi:10.5194/acp-9-51552009, 2009.

Heringa, M. F., DeCarlo, P. F., Chirico, R., Tritscher, T., Dommen, J., Weingartner, E., Richter, R., Wehrle, G., Prévôt, A. S. H., and Baltensperger, U.: Investigations of primary and secondary particulate matter of different wood combustion appliances with a high-resolution time-of-flight aerosol mass spectrometer, Atmos. Chem. Phys., 11, 5945-5957, doi:10.5194/acp-11-5945- 
2011, 2011.

IPCC: Contribution of Working Group I to the Fourth Assessment Report of the Intergovernmental Panel on Climate Change, ISBN 978-0-521-88009-1, Cambridge University Press, 2007.

Jimenez, J. L., Canagaratna, M. R., Donahue, N. M., Prevot, A. S. H., Zhang, Q., Kroll, J. H., DeCarlo, P. F., Allan, J. D., Coe, H., Ng, N. L., Aiken, A. C., Docherty, K. S., Ulbrich, I. M., Grieshop, A. P., Robinson, A. L., Duplissy, J., Smith, J. D., Wilson, K. R., Lanz, V. A., Hueglin, C., Sun, Y. L., Tian, J., Laaksonen, A., Raatikainen, T., Rautiainen, J., Vaattovaara, P., Ehn, M., Kulmala, M., Tomlinson, J. M., Collins, D. R., Cubison, M. J., Dunlea, E. J., Huffman, J. A., Onasch, T. B., Alfarra, M. R., Williams, P. I., Bower, K., Kondo, Y., Schneider, J., Drewnick, F., Borrmann, S., Weimer, S., Demerjian, K., Salcedo, D., Cottrell, L., Griffin, R., Takami, A., Miyoshi, T., Hatakeyama, S., Shimono, A., Sun, J. Y., Zhang, Y. M., Dzepina, K., Kimmel, J. R., Sueper, D., Jayne, J. T., Herndon, S. C., Trimborn, A. M., Williams, L. R., Wood, E. C., Middlebrook, A. M., Kolb, C. E., Baltensperger, U., and Worsnop, D. R.: Evolution of organic aerosols in the atmosphere, Science, 326, 1525-1529, doi:10.1126/science.1180353, 2009.

Johnson, T. V.: Diesel emission control in review, SAE International Journal of Fuels and Lubricants, 1, 68-81, 2008.

Jordan, A., Haidacher, S., Hanel, G., Hartungen, E., L., M., Seehauser, H., Schottkowsky, R., Sulzer, P., and Märk, T. D.: A high resolution and high sensitivity proton-transfer-reaction time-offlight mass spectrometer (PTR-TOF-MS), Int. J. Mass Spectrom., 122-128, 2009.

Kroll, J. H., Donahue, N. M., Jimenez, J. L., Kessler, S. H., Canagaratna, M. R., Wilson, K. R., Altieri, K. E., Mazzoleni, L. R., Wozniak, A. S., Bluhm, H., Mysak, E. R., Smith, J. D., Kolb, C. E., and Worsnop, D.: Carbon oxidation state as a metric for describing the chemistry of atmospheric organic aerosol, Nature Chem., 3, 133-139, 2011.

Matthew, B. M., Middlebrook, A. M., and Onasch, T. B.: Collection efficiencies in an Aerodyne Aerosol Mass Spectrometer as a function of particle phase for laboratory generated aerosols, Aerosol Sci. Technol., 42, 884-898, 2008.

Middlebrook, A. M., Bahreini, R., Jimenez, J. L., and Canagaratna, M. R.: Evaluation of composition-dependent collection efficiencies for the Aerodyne aerosol mass spectrometer using field data, Aerosol Sci. Technol., 46, 258-271, 2012.

Ng, N. L., Kroll, J. H., Chan, A. W. H., Chhabra, P. S., Flagan, R. C., and Seinfeld, J. H.: Secondary organic aerosol formation from m-xylene, toluene, and benzene, Atmos. Chem. Phys., 7, 3909-3922, doi:10.5194/acp-7-3909-2007, 2007.

Ng, N. L., Canagaratna, M. R., Zhang, Q., Jimenez, J. L., Tian, J., Ulbrich, I. M., Kroll, J. H., Docherty, K. S., Chhabra, P. S., Bahreini, R., Murphy, S. M., Seinfeld, J. H., Hildebrandt, L., Donahue, N. M., DeCarlo, P. F., Lanz, V. A., Prévôt, A. S. H., Dinar, E., Rudich, Y., and Worsnop, D. R.: Organic aerosol components observed in Northern Hemispheric datasets from Aerosol Mass Spectrometry, Atmos. Chem. Phys., 10, 46254641, doi:10.5194/acp-10-4625-2010, 2010.

Nordin, E. Z., Eriksson, A. C., Roldin, P., Nilsson, P. T., Carlsson, J. E., Kajos, M. K., Hellén, H., Wittbom, C., Rissler, J., Löndahl, J., Swietlicki, E., Svenningsson, B., Bohgard, M., Kulmala, M., Hallquist, M., and Pagels, J. H.: Secondary organic aerosol formation from idling gasoline passenger vehicle emissions investi- gated in a smog chamber, Atmos. Chem. Phys., 13, 6101-6116, doi:10.5194/acp-13-6101-2013, 2013.

Odum, J. R., Hoffmann, T., Bowman, F., Collins, D., Flagan, R. C., and Seinfeld, J. H.: Gas/particle partitioning and secondary organic aerosol yields, Environ. Sci. Technol., 30, 2580-2585, 1996.

Odum, J. R., Jungkamp, T. P. W., Griffin, R. J., Forstner, H. J. L., Flagan, R. C., and Seinfeld, J. H.: Aromatics, reformulated gasoline, and atmospheric organic aerosol formation, Environ. Sci. Technol., 31, 1890-1897, 1997.

Paulsen, D., Dommen, J., Kalberer, M., Prévôt, A. S. H., Richter, R., Sax, M., Steinbacher, M., Weingartner, E., and Baltensperger, U.: Secondary Organic Aerosol Formation by Irradiation of 1, 3, 5-Trimethylbenzene-NO x-H2O in a New Reaction Chamber for Atmospheric Chemistry and Physics, Environ. Sci. Technol., 39, 2668-2678, 2005.

Pfaffenberger, L., Barmet, P., Slowik, J. G., Praplan, A. P., Dommen, J., Prévôt, A. S. H., and Baltensperger, U.: The link between organic aerosol mass loading and degree of oxygenation: an ?pinene photooxidation study, Atmos. Chem. Phys., 13, 64936506, doi:10.5194/acp-13-6493-2013, 2013.

Phuleria, H. C., Geller, M. D., Philip, M., and Sioutas, C.: Sizeresolved emissions of organic tracers from light-and heavy-duty vehicles measured in a California roadway tunnel, Environ. Sci. Technol., 40, 4109-4118, 2006.

Presto, A. A., Nguyen, N. T., Ranjan, M., Reeder, A. J., Lipsky, E. M., Hennigan, C. J., Miracolo, M. A., Riemer, D. D., and Robinson, A. L.: Fine particle and organic vapor emissions from staged tests of an in-use aircraft engine, Atmos. Environ., 45, 3603-3612, 2011.

Prinn, R. G., Huang, J., Weiss, R. F., Cunnold, D. M., Fraser, P. J., Simmonds, P. G., McCulloch, A., Harth, C., Salameh, P., O'Doherty, S., and others: Evidence for substantial variations of atmospheric hydroxyl radicals in the past two decades, Science, 292, 1882-1888, 2001.

Robinson, A. L., Donahue, N. M., Shrivastava, M. K., Weitkamp, E. A., Sage, A. M., Grieshop, A. P., Lane, T. E., Pierce, J. R., and Pandis, S. N.: Rethinking organic aerosols: Semivolatile emissions and photochemical aging, Science, 315, 1259-1262, doi:10.1126/science.1133061, 2007.

Saathoff, H., Naumann, K. H., Schnaiter, M., Schock, W., Mohler, O., Schurath, U., Weingartner, E., Gysel, M., and Baltensperger, U.: Coating of soot and $\left(\mathrm{NH}_{4}\right) 2 \mathrm{SO}_{4}$ particles by ozonolysis products of [alpha]-pinene, J. Aerosol Sci., 34, 1297-1321, 2003.

Sandradewi, J., Prevot, A. S. H., Weingartner, E., Schmidhauser, R., Gysel, M., and Baltensperger, U.: A study of wood burning and traffic aerosols in an Alpine valley using a multi-wavelength Aethalometer, Atmos. Environ., 42, 101-112, 2008.

Schmitz, T., Hassel, D., and Weber, F.-J.: Determination of VOCcomponents in the exhaust of gasoline and diesel passenger cars, Atmos. Environ., 34, 4639-4647, 2000.

Seinfeld, J. H. and Pandis, S. N.: Atmospheric Chemistry and Physics, edited by: Seinfeld, J. H., and Pandis, S. N., Wiley, p. 196, New York, 2006.

Song, C., Na, K., Warren, B., Malloy, Q., and Cocker, D. R.: Impact of propene on secondary organic aerosol formation from $\mathrm{m}$ xylene, Environ. Sci. Technol., 41, 6990-6995, 2007.

Taira, M. and Kanda, Y.: Continuous generation system for lowconcentration gaseous nitrous acid, Anal. Chem., 62, 630-633, 
1990.

Weilenmann, M., Favez, J.-Y., and Alvarez, R.: Cold-start emissions of modern passenger cars at different low ambient temperatures and their evolution over vehicle legislation categories, Atmos. Environ., 43, 2419-2429, 2009.

Williams, L. R., Gonzalez, L. A., Peck, J., Trimborn, D., McInnis, J., Farrar, M. R., Moore, K. D., Jayne, J. T., Robinson, W. A., Lewis, D. K., Onasch, T. B., Canagaratna, M. R., Trimborn, A., Timko, M. T., Magoon, G., Deng, R., Tang, D., de la Rosa Blanco, E., Prévôt, A. S. H., Smith, K. A., and Worsnop, D. R.: Characterization of an aerodynamic lens for transmitting particles $>1$ micrometer in diameter into the Aerodyne aerosol mass spectrometer, Atmos. Meas. Tech. Discuss., 6, 5033-5063, doi:10.5194/amtd-6-5033-2013, 2013. 